\title{
THE SURVIVAL AND TRANSFORMATION OF ANNULAR PACCHAS IN CUSCO: AN EXAMPLE OF ARTISTIC AND IDEOLOGICAL CONTINUITY AND CHANGE
}

\author{
LA SOBREVIVENCIA Y TRANSFORMACIÓN DE PACCHAS ANULARES \\ EN EL CUSCO: UN EJEMPLO DE CONTINUIDAD Y CAMBIO ARTÍSTICO \\ E IDEOLÓGICO
}

RICHARD L. BURgerA

Pacchas were ritual vessels used in libations and expressed elements of pre-Hispanic cosmology in the Andes long after the Spanish conquest. This article describes, for the first time, annular pacchas from Cusco from the Colonial Period and the $19^{\text {th }}$ and $20^{\text {th }}$ centuries. These pacchas are distinguished by their ring-shaped chamber and short vertical spout and survived as a symbol and valued ritual element for Andean people from AD 1532 to the $20^{\text {th }}$ century. Their role in rain and fertility rituals is expressed by their shape and by the representation of the amaru, the mythical snake of Andean cosmovision.

Keywords: Pacchas, Keros, Andean religion, Kubler, Amaru, Cherubs, Cusco, Colonial ceramics, Folk art, Culture change.

Las pacchas son vasijas rituales utilizadas en ofrendas de líquidos y han funcionado como medio de expresión de elementos de la cosmología prehispánica en Cusco, incluso mucho después de la Conquista. En este artículo, se describen por primera vez las pacchas anulares del Período Colonial y los siglos XIX y XX, las que se distinguen por su cámara en forma de anillo y su boca vertical corta. Estas pacchas post-Conquista sobrevivieron como un implemento ritual valorizado desde 1532 DC hasta el siglo $\mathrm{xx}$. Su rol en ceremonias de lluvias y en la fertilidad se manifiesta en su forma y en la representación del amaru, la mítica serpiente de la cosmovisión andina.

Palabras clave: Pacchas, Keros, Religión andina, Kubler, Amaru, Angelito, Cusco, Cerámica colonial, Arte popular, Cambio cultural.

\section{INTRODUCTION}

While an undergraduate at Yale College, I was surprised to hear George Kubler, the eminent art historian, declare that the traditions of Pre-Columbian art had been extinguished by the Spanish Conquest and that the art produced subsequently in the Andes had to be understood as variants of European forms shaped by Christian religious beliefs (Kubler 1961). In Kubler's opinion, even those images strongly reminiscent of PreColumbian motifs should be assumed to have taken on a new Christian meaning within the context of colonial artistic production and society. This idea, popularized under the term "disjunction", was inspired by Erwin Panofsky's interpretation of the rejection of paganism in the Old World and the resulting reinterpretation of classical objects by medieval Christian artists.

Beginning with the $500^{\text {th }}$ Anniversary of Columbus's arrival in the New World, there has been an increased interest in what some have called the Clash of Cultures that has not subsided. A series of blockbuster exhibits in New York and other cities explored the relationship between European artistic traditions and the Latin American world during the Colonial Period. These exhibits, deeply influenced by Kubler's work, were dominated by oil paintings, church paraphernalia, and other classes

A Richard L. Burger, Department of Anthropology, Yale University. Orcid: 0000-0002-0664-0645. E-mail: richard.burger@yale.edu 
of objects introduced by the European invaders. The one thing these varied objects shared was that they had no antecedent in the Andes. The work of anthropologists John Rowe (1961) and Jorge Flores Ochoa (Flores Ochoa et al. 1998), who analyzed keros (Andean wooden drinking vessels) in order to understand the role of these "art objects" as possible tools of cultural resistance and survival, was not considered.

In 2004 an exhibit entitled The Colonial Andes: Tapestries and Silverwork, 1530-1830 was held at the Metropolitan Museum of Art. Its catalog featured articles written by Tom Cummins and others from a new generation of art historians. Fine Inca weavings were included together with colonial textiles that bore the imprint of pre-Conquest artistic traditions. Despite this, the exhibit and resulting catalog was dominated by chalices, monstrances, oil paintings of Santa Rosa, incense burners, and leather chests (Phipps et al 2004).

But what about those classes of colonial Andean objects besides textiles that were important to preConquest Andean people but were alien to the Old World? What was their fate following the Spanish invasion and the repeated efforts of Roman Catholic priests to extirpate indigenous rituals and their material expression? Were these artistic traditions consigned to extinction as Kubler suggested or did they have a longer and more complex life history (Quilter 1997)? It is now recognized by many ethnographers, linguists, historians, and even art historians, that Andean cosmology and epistemology survived and continued to develop among Quechua and Aymara speakers in the centuries following the Spanish conquest (e.g., Cummins \& Mannheim 2011), so it would be expected that there would be artistic expressions of this process in materials other than traditional Andean textiles. Surprisingly, despite the significant change in scholarly attitudes regarding the longevity and survival of indigenous culture in Latin America (Sundstrom \& DeBoer 2012), little attention has been devoted to post-Hispanic Andean objects that express this continuity.

\section{THE STUDY OF PACCHAS}

It was this problem that first attracted me to pacchas, a class of vessels used for the making of libations to the deities and for ritual drinking. My interest follows in the footsteps of archaeologist Samuel Lothrop who observed:
Two distinctive types of wooden-drinking vessels, known as keros and pacchas, were manufactured in Peru both before and after the Spanish conquest. Thus, they exemplify the transition from archaeology to history and ethnology [...] Each has counterparts in pottery, metal or stone [...] Keros are fairly common; pacchas are exceedingly rare. Little has been written about either group (Lothrop 1950: 233).

This statement published 70 years ago is no longer true for keros, which have attracted considerable scholarly interest over the last two decades. The literature on keros is well known and I will not dwell on these postConquest vessels here (e.g., Cummins 2002, Flores Ochoa et al. 1999). But what about pacchas, the other class of ritual vessels highlighted by Lothrop? The potential significance of pacchas for Andean research was recognized by English anthropologist Thomas Joyce in the early twentieth century. Joyce was intrigued by two unusual wooden objects featured in a 1920 exhibit in the Burlington Fine Arts Club in London. After studying them and other similar objects, he wrote a 1922 article entitled "The 'Paccha' of Ancient Peru”. In this publication, Joyce linked the mysterious wooden specimens on display in London with an account written by Amédée-Francois Frézier, a French military engineer, explorer and spy. Frézier's report dates to around 1712, when he was traveling among the Mapuche (referred to as Araucanians by Joyce) who were living south of Chile's Maule River. Frézier observed a group of Mapuche individuals engaged in ritual drinking using a large vessel strikingly similar to the object in the Burlington Fine Arts Club exhibit. According to Frézier, the Mapuche called these items paquecha. In a footnote, Joyce writes "It must be remembered that Frézier was a Frenchman, writing in French, and that the spelling Paquecha, according to French phonetics corresponds exactly to the Paccha (with a faucal gasp between the c's) which is recorded in Middendorf's dictionary...". In addition, Joyce connected the $18^{\text {th }}$ century wooden paccha from Chile to examples from Peru housed at the Harvard Peabody Museum. Joyce recognized that these belonged to a class of vessels that began to be produced before the Incas and that continued to be made after the Spanish conquest. Thus, Joyce recognized that the pacchas belonged to a long Andean tradition spanning, as Lothrop later observed, archaeology, history and ethnography.

Utilizing a quechua dictionary compiled by the $19^{\text {th }}$ century Swiss traveler Johann von Tschudi, Joyce 


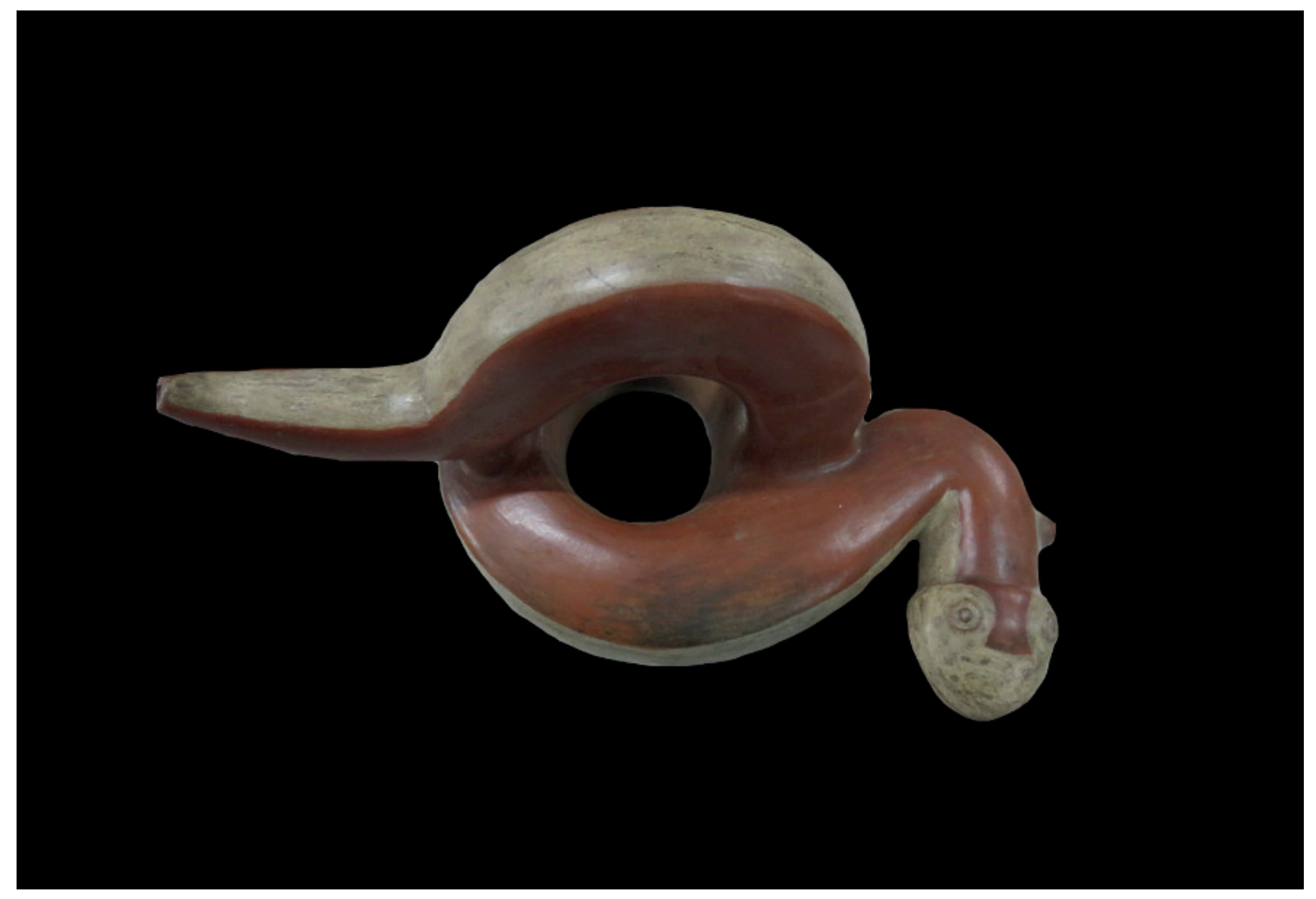

Figure 1. Ceramic annular paccha in the form of a snake. Chimu-Inca style, north coast of Peru, Late Horizon. MNAAH, Lima. Figura 1. Paccha cerámica de base anular en forma de serpiente. Estilo Chimú-Inca, costa norte de Perú, Horizonte Tardío, MNAAH, Lima.

observed that the term paccha referred to dripping, running or gushing water (Joyce 1922: 145). He linked this translation to the dual zig-zag channels found on Inca and colonial wooden pacchas. Moreover, Joyce compared these designs to similar ones on Inca stone outcrops or boulders, such as the ones at Qenqo in Cusco, and suggested that these carved stones should be considered "permanent pacchas". Based on this body of evidence, Joyce concluded that pacchas such as the ones in the Burlington Fine Arts Club, were Central Andean ritual objects spread by the Inca empire, and that these objects continued to be used during the eighteenth century in rituals that focused on the movement of liquids.

Several decades later, the analysis of pacchas as vessels for ceremonial libations of chicha or water was taken up again by Rebecca Carrión Cachot (1955), a student of Julio C. Tello and one-time director of the Museo Nacional de Antropología y Arqueología. Carrión observed that pacchas are not practical in a utilitarian sense; they are difficult to fill and are impractical to use as serving vessels. In her interpretation, their form was symbolic, and directly related their use as ritual paraphernalia in libations. In her article, "El culto al agua en el antiguo Perú: la paccha, elemento cultural panandino", she documents numerous examples of pacchas from various prehispanic cultures, thereby confirming both the diversity and longevity of pacchas in ancient Peru. Drawing upon the collections in Peru's national museum, she showed that pacchas were produced by many prehistoric cultures such as the Moche, Recuay, Pachacamac (i.e., Middle Horizon), Chimu, and Inca (Carrión 1955: láminas XV-XXv). A photograph of one of the objects that interested Carrión, a Chimu-Inca style paccha, is presented here (fig. 1). Carrión's focus was primarily archaeological and she devoted little attention to historic or ethnographic pacchas, although she did relate the prehispanic pacchas to later ethnohistoric descriptions of Andean rituals and myths concerning rainfall and water as well as the ritual actions taken to ensure adequate rainfall through interaction with supernatural forces. 
Following Carrión's landmark contribution, the subject of pacchas remained largely ignored by investigators. The work done by anthropologist Catherine Allen, however, is one conspicuous exception. Allen had considered writing her doctoral thesis on keros and pacchas and never lost interest in them. In her article The Incas Have Gone Inside: Pattern and Persistence in Andean Iconography she writes the following:

Using ethnographic, iconographic, and historical research, I focus on the decoration of wooden drinking vessels called keros and pacchas. These wooden tumblers, which developed out of pre-Columbian antecedents and are still in use as I write these words in the year 2001, bear one of the richest iconographies of post-conquest Peru. Judiciously interpreted, they may help us elucidate an Andean semiotic within its cultural context (Allen 2002: 182).

The relationship of pacchas to flowing water over stones from springs and other natural sources was discussed by Allen (2002) on the basis of contemporary ethnographic work in Cusco. The use of pacchas resonates with the traditional Andean model of water being cycled from the sky to the mountains and then through and under the earth until it reaches the ocean, only to be returned again to the sky. This concept is central to Andean cosmology and religious practice, and the functioning of this circulatory system is necessary for the success of herds and crops, as well as for the health of the community. Thus, it requires constant ritual libations in order to maintain the reciprocal relationship between this world and the forces beyond it (apus, ancestors, Pachamama, etc.) that are crucial to its functioning (Allen 2002: 196-200). A nuanced understanding of the indigenous cosmology underlying this has been developed by Bruce Mannheim and Tom Cummins using insights from linguistic analysis of Quechua. They illustrate their argument using Inca and early colonial pacchas (Cummins \& Mannheim 2011). There are at least two regions of the Central Andes in which the use of pacchas has been reported from the second half of the $20^{\text {th }}$ century: one is in the province of Paruro, Cusco (Barrionuevo 1963), and the other is the village of Alcamenga in Ayacucho. In Alcamenga, pacchas were used to drink chicha during the Fiesta del Agua (Ulfe 2004: 81).

As noted, Lothrop (1950: 233) observed that the study of pacchas, like the study of keros, has potential for better understanding the transformation of highland
Andean culture from prehispanic times to the present. To begin this process of understanding, I offer a description and analysis of a distinctive group of pacchas that has not previously received attention. Although pacchas were crafted from many materials, including wood, silver, and stone, perhaps the most common material in both prehispanic and post-Conquest times was pottery. Carrión reviewed a variety of ceramic pacchas from prehispanic times, but no one has offered a comparable overview for post-Conquest pacchas. Among the latter, the most common are circular in form and frequently referred to as cochas (or qochas), the Quechua term for glacial lakes (Flores Ochoa et al. 1998: 63-65). In post-Conquest times these ceramic cochas are often organized into concentric circular zones that are connected by unseen tubes hidden within the vessel and pour libations out of short horizontal spouts (e.g., Stasny 1991-1992, Mujica et al. 2011: 88-89, 102-103).

In this article, rather than considering the numerous cochas that exist in museums and private collections, I focus on a less common class of vessels that I refer to as annular pacchas. These have a chamber in the form of a tubular ring and a short vertical spout (or spouts). The circular or ring-shaped form of these ceramic vessels forces the liquid poured into it to flow through the tubular chamber, thereby circulating the liquid through the ritual vessel, paralleling the way in which water is believed to circulate through the universe. The bottom, or underside, of the ring-shaped chamber is always left unpolished and undecorated, and its surface is slightly flattened to support the vessel in a stable position. Although circular in shape, for the purposes of this discussion I refer to the front of the annular paccha as "the part of the object that presents itself to view or that is normally seen or used first". Many of the annular pacchas are decorated with a modeled human or zoomorphic face and I assume that the viewer initially sees the vessel from a position in which these sculpted faces can be appreciated. When this occurs, the viewer can be said to be looking at the front of the vessel (fig. 2). When viewing it from the opposite side, the viewer is unable to see these faces and instead sees an undecorated or nondescript portion of the paccha's spout or chamber. This is referred to as the rear or back of the paccha (fig. 3). 


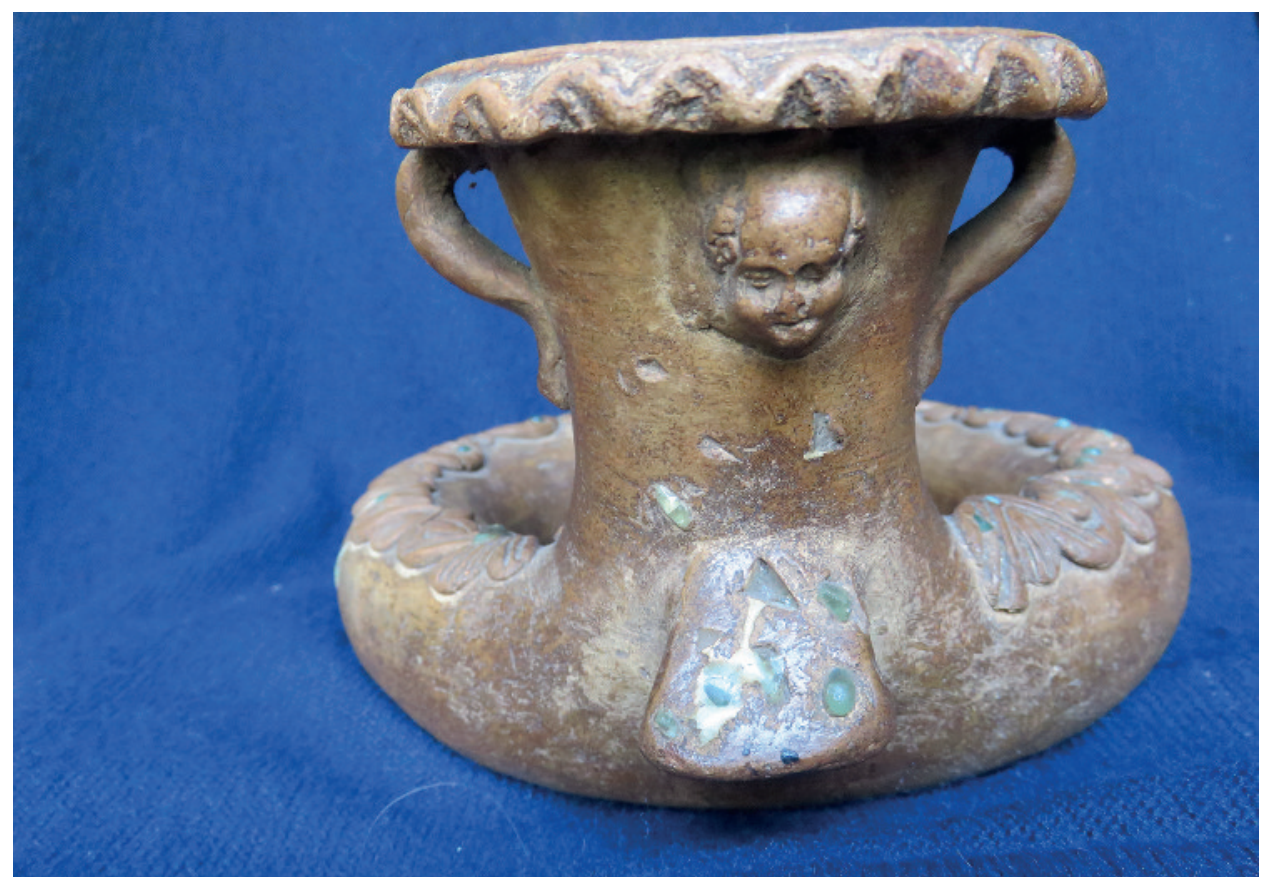

Figure 2. Ceramic annular paccha with strap handles, applique lip band, cherub face, and inlayed colored glass (PC-1). Colonial Period, Cusco. Private collection. Figura 2. Paccha cerámica de base anular con mangos de correa, venda de labios sobrepuesta, cara de querubín y vidrio de color incrustado (PC-1). Período Colonial, Cusco. Colección privada.

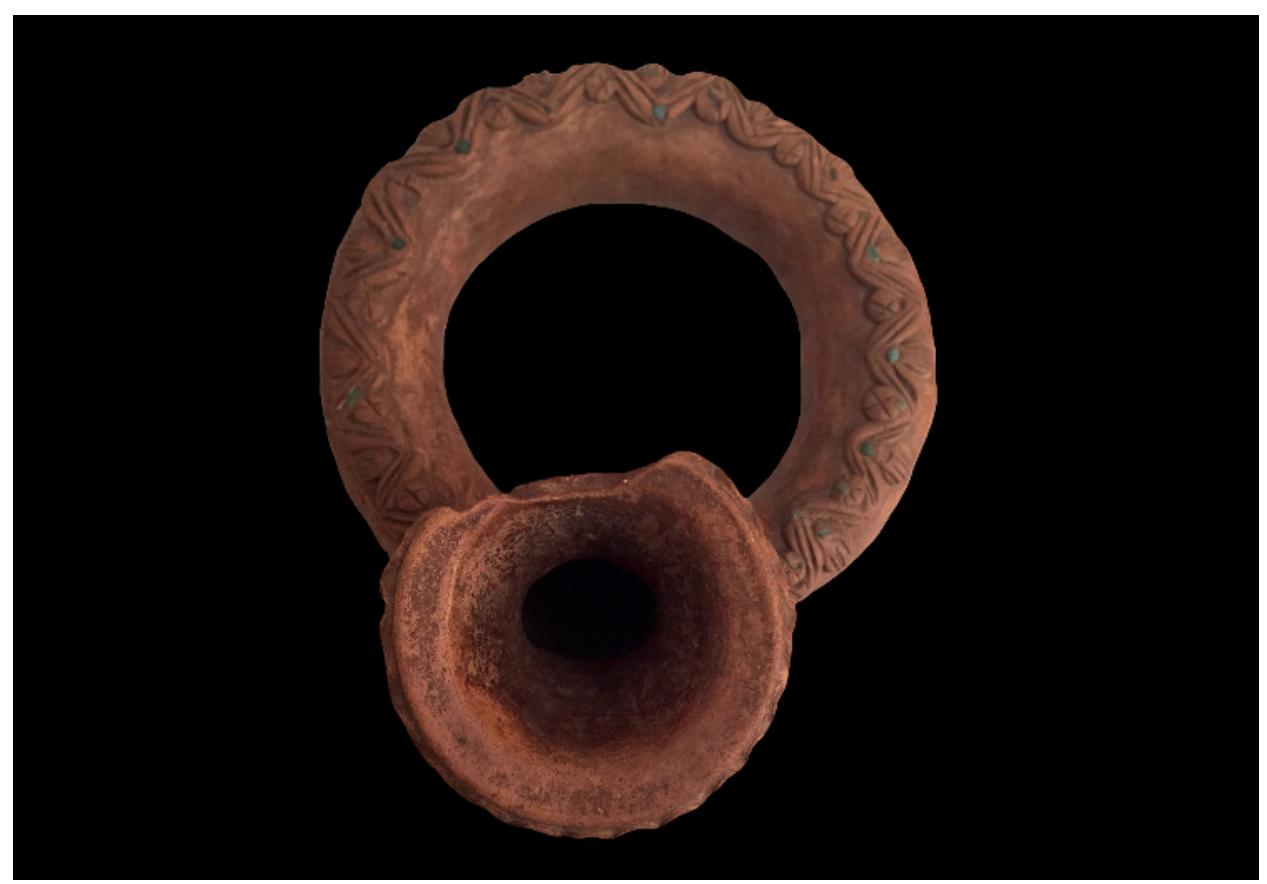

Figure 3. Decorated ring-shaped chamber of ceramic annular paccha from Cusco with image of amaru adorned with inlayed glass and stylized marine elements (PC-1). Colonial Period, Cusco. Private collection. Figura 3. Cámara circular decorada de paccha cerámica de base anular del Cusco con imagen de amaru, adornada con vidrio incrustado y elementos marinos estilizados (PC-1). Período Colonial, Cusco. Colección privada. 


\section{PREHISPANIC ANTECEDENTS}

Like keros and cocha-style pacchas, annular or ring-shaped pacchas have antecedents deep in the prehistoric past. Pacchas with ring shaped chambers were produced by many cultures in ancient Ecuador and Peru. This class of vessel includes the paccha from Santa Ana-La Florida in the eastern slopes of Ecuador that is believed to date to before 3000 BCE (Valdez 2013: 54a). Pacchas with circular chambers have also been documented for the $1^{\text {st }}$ millennium BC for the Chorrera culture of coastal Ecuador and the Cupisnique culture of the Peruvian north coast (Lathrap et al. 1975, Alva 1986), as well as many later prehispanic cultures.

It should be noted, however, that many of these antecedents do not have the distinctive vertical spout or spouts characterizing the post-Conquest annular pacchas that are the focus of this article. The vessel from Santa Ana-La Florida, for example, features a stirrup-spout, and the Chorrera example referred to has a spout-and-bridge attached to its ring-shaped chamber. Other pacchas with a circular chamber lack vertical spouts entirely, such as the Inca example from Peru's Museo Nacional de Arqueología, Antropología e Historia illustrated in figure 1. There are, however, prehispanic annular pacchas with vertical spouts that offer a clear antecedent for the post-Conquest ritual vessels that are the focus of this study. These pacchas, dating to the Late Intermediate Period (AD 1000-1420) and Late Horizon (AD 1420-1532), come from the Peruvian coast and are usually identified as the products of the Chimu or Chimu-Inca culture (e.g., Carrión Cachot 1955: fig. xxih).

Among the pre-Conquest annular pacchas, both with and without vertical spouts, one of the most common decorative motifs is that of a serpent or amaru (Carrión 1955: 78, fig. xxia-d). According to Fedora Martinez Grimaldo (2009: 9), the amaru is a mythical serpent-feline creature of extraordinary power that emerges from the $u k u$-pacha (underworld), influences the living beings of kay-pacha (this world), and is closely associated with the atmospheric phenomena of hananpacha (upper world). Thus, the amaru can be viewed as a meteorological divinity who normally lavishes waters on the crops and the herds, but also unleashes floods and landslides that destroy cropland (Ortmann 2002). The amaru is often represented as an anaconda, a large serpent with circular markings on its body that moves between rivers and land in the tropical forest. It is possible that the coiled form of the serpent may have been the inspiration of the tube-shaped or ringed-shaped body of the chamber of the annular paccha. The most beautiful of the prehispanic snake-shaped annular pacchas were produced during the late $15^{\text {th }}$ and early $16^{\text {th }}$ century by potters of the Peruvian north coast in the Chimu-Inca style (fig. 1). The amaru is sometimes symbolized by the zig-zag motif that is found on Inca and colonial wooden pacchas such as those illustrated by Joyce (1922: fig. 1, Plates X-XII) and Lothrop (1950: fig. 67)

Pacchas continued to be made and used after the Spanish conquest and although wooden pacchas have attracted the most interest from art historians and archaeologists, ceramic pacchas likewise shed light on the experience of Quechua-speaking communities after the Conquest. In this article I will consider the style and technology of ceramic annular pacchas as well as the iconography that adorns them. To better appreciate the patterns of transformation and continuity, the sample of post-Conquest annular pacchas described here has been organized into three sequential periods: Colonial (1532-1824), the $19^{\text {th }}$ century following Peruvian Independence (1824-1899), and the $20^{\text {th }}$ century. The objects mainly come from public museums and private collections in Lima and Cusco and estimates of their age and place of origin are based on incomplete evidence. Chronological placement is estimated using the documentary data available, the style of the objects, the technology of their production, and the judgment of the author.

I was able to locate thirteen annular pacchas in my investigations, but additional examples probably exist in Peru and abroad. Remarkably, this is the first time that images of post-Conquest annular pacchas have been described or illustrated. The indigenous name for these objects is uncertain, but the term pilli may have been used for them at least until the early $20^{\text {th }}$ century. This term appears in the 1919 Catálogo de las Antigüedades Incanas que constituyen el Museo Muñiz (Gänger 1914). According to the catalog, in the collection belonging to the prominent politician José Lucas Caparo Muñiz there were wheel-shaped vessels of three different sizes known as pilli that were used to drink chicha (Guevara 1997: 216). These pieces were eventually donated to the Universidad Nacional San Antonio Abad Cusco and were incorporated into the collection of UNSAAC's archaeology museum, currently known as the Museo Inka. 


\section{ANNULAR PACCHAS FROM COLONIAL CUSCO AD 1532-1821}

The first annular paccha (PC-1) that I examined comes from an anonymous private collection (figs. 2 and 3). It was purchased in Cusco in the early 1990s. The tubular form of the chamber leaves no doubt about its prehispanic roots, but the applique lip band with repeating crescents that decorates the spout shows colonial Spanish influence as do the curvilinear strap-handles attached to the spout (fig. 4; Mujica et al. 2011:43, 114). Both features are ornamental and serve no utilitarian function. Thus, the vessel form of PC-1 is a fusion of prehispanic and Iberian elements, although from a functional perspective the vessel's ability to serve as a paccha remained central and unhindered. Based on the Spanish elements incorporated into the form, its date of production is estimated to be the xvinth century. The lip of the paccha's spout is chipped. This kind of damage would be expected to occur on a ritual drinking vessel made of pottery (fig. 3).

Like the form, the decoration of the paccha (PC1) shows a mixture of Andean and Iberian elements. An applique modeled face in bas-relief (10 mm thick) was placed in the center of the spout and it has the appearance of an angel or cherub in baroque style. Such faces appear on colonial artwork from Cusco in many contexts, such as the bronze door ornaments from the La Compañía de Jesús, a church located in Cusco's Plaza de Armas (fig. 5).

Beneath the cherub head on PC-1 is a projecting quadrilateral slab with inlays placed into carved recesses. The inlays consist of five small droplets of green glass (fig. 2) on depressions in the slab and additional ones on the neck of the spout. The decorated slab projects $3 \mathrm{~cm}$ out from the spout. In searching for an explanation of the shelf-like projection, I was struck by an $18^{\text {th }}$ century Cuzqueño oil painting of the Archangel Gabriel (fig. 6) in which he is dressed in an elaborate rectangular cloth bib that covers his chest (Tom Cummins 2019, personal communication). The elaborate bib was probably made of gauze and trimmed with lace, a style popular in the late $17^{\text {th }}$ and early $18^{\text {th }}$ century before it was replaced by the jabot (Maya Stanfield-Mazzi 2019, personal communication). Could the slab projecting from the paccha spout be an Andean interpretation of this exotic European clothing item? This painting is not unique. Contemporary portraits of Archangel Gabriel

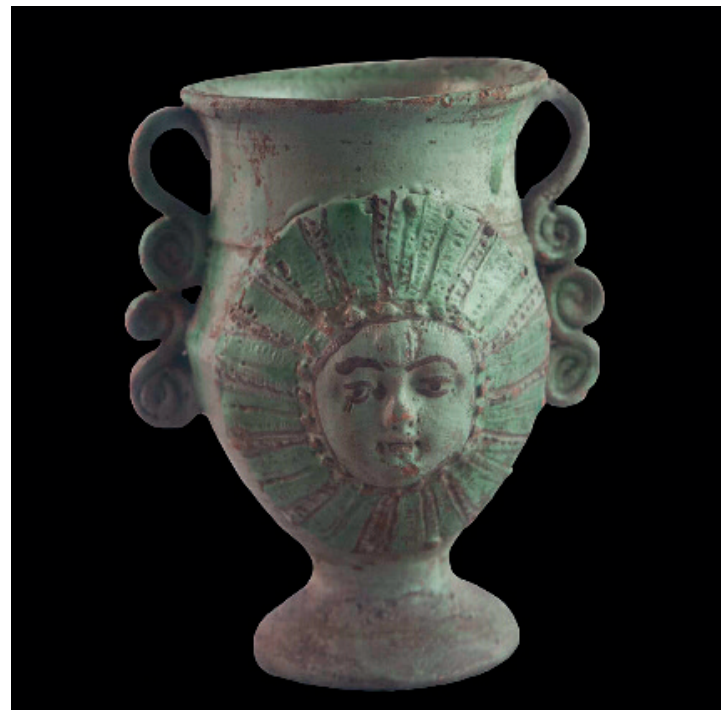

Figure 4. Chalice with curvilinear strap handle and frontal face. Colonial Period, Cusco Jaime Liébana Collection, Lima. Figura 4. Cáliz con mangos curvos de correa y cara frontal. Período Colonial, Cusco. Colección de Jaime Liébana, Lima.

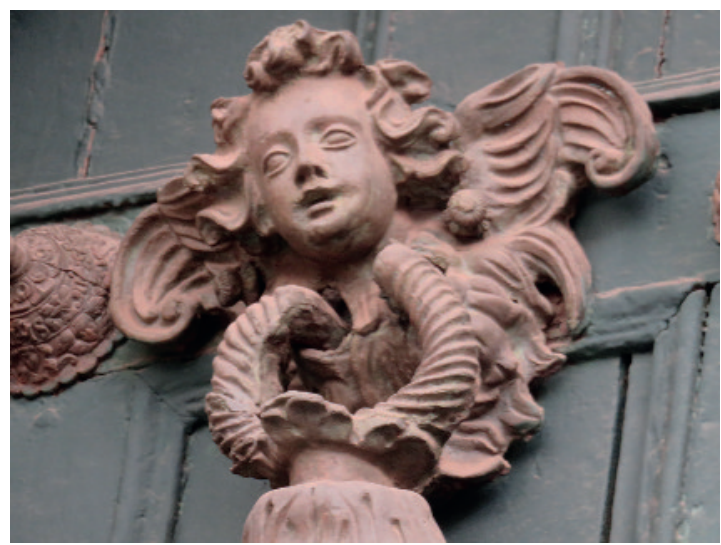

Figure 5. Door ornament in the form of a cherub face. Iglesia de la Compañía, Plaza de Armas, Cusco. Colonial Period. Figura 5. Decoración de puerta con forma de cara de querubín. Iglesia de la Compañía, Plaza de Armas, Cusco. Período Colonial.

and other angels from Cusco show this bib, although not all of them are as fancy as the one illustrated here.

Most of the decoration on paccha PC-1 appears on the upper surface of the tubular chamber (fig. 3). It consists of a raised incised zig-zag band that is inlaid with at least twenty small droplets of green or blue glass. At the interstices of the band are small applique elements that alternate with each other. These secondary 
elements are ovoid with vertical striations or circular with an incised $\mathrm{X}$ or cross motif. The ovoid elements with striations are reminiscent of the representation of spondylus shell on silver disks of the Chimu culture, where they are sometimes associated with curvilinear bands representing the ocean (Pillsbury 2003). The pairing of spondylus and a contrasting sea shell such as a strombus shell is widespread in prehistoric times and continues to occur in highland Andean ceremonies. I believe that the ovoid forms on PC-1 may represent sea shells, perhaps spondylus, and that the round forms stand for shells of some other kind, thereby constituting a dual contrast with marine associations. The zig- zag band from which these forms hang symbolizes the serpent or amaru. The bottom or underside of the vessel was left unpolished and undecorated, which is not surprising considering that this portion of the vessel would not be visible under most circumstances.

The vessel was fired at a relatively low temperature in an oxidizing environment after being polished to achieve a low luster. Although the paccha was not fired at a high temperature, it has green and blue glass encrustations set into the "bib" and the body of the amaru. Many of these are located at the apexes or hinges of the zig-zag motif, but some were placed in recesses carved into the circular and trapezoidal icons. Technical analysis confirmed that the inlays were man-made glass rather than obsidian or some other natural material. The glass must have been produced separately at a much higher temperature than the firing temperature of the clay pacchas. The presence of the glass inlays confirms that PC-1 was produced after the Spanish Conquest and probably dates to early colonial times.

I was fortunate to be given access to the collections of the Museo Inka in Cusco and was excited to find that they had an annular paccha (MI-1) that is very similar to PC-1 (figs. 7 and 8). The two are so similar, in fact, that MI-1 may be hypothesized to constitute a pair with PC-1. This would not be surprising since in prehispanic times vessels were often produced in matching pairs. In the Andes, "matching" vessels usually differ from each other slightly in size and detail. The Museo Inka paccha has the same form and decoration as PC-1, but it is slightly larger in size (table 1). It also varies in some details: for example, MI-1's quadrilateral bib-like projection was left undecorated.

The colonial paccha (MI-1) was accessioned into the collection of the Museo Inka in 1941 by its director,

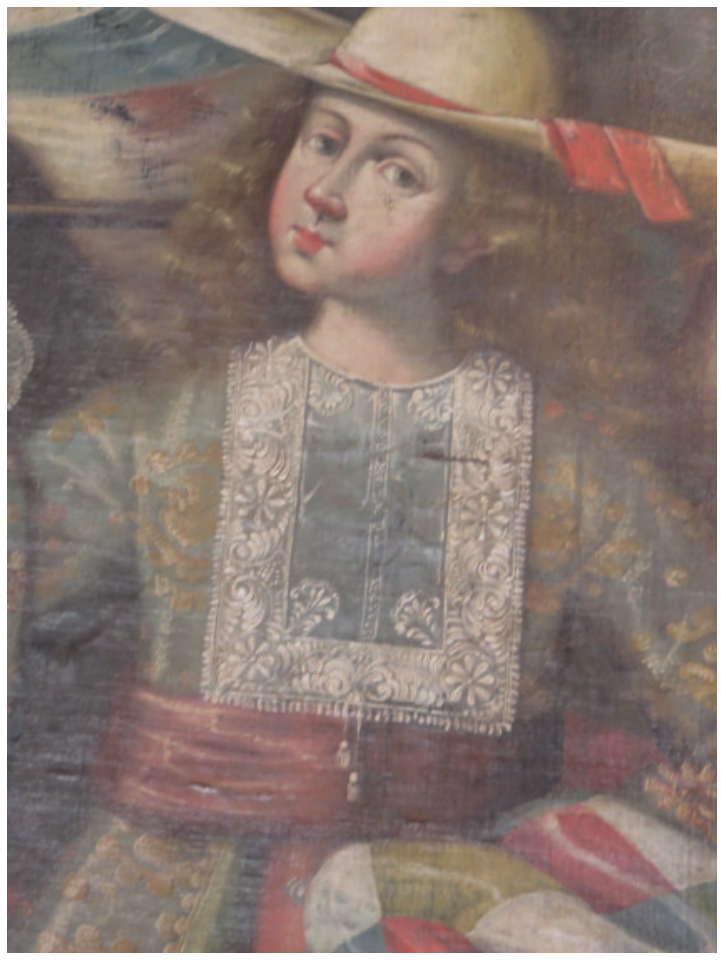

Figure 6. Painting of the Archangel Gabriel wearing ornamental bib. Colonial Period (late $17^{\text {th }} / 18^{\text {th }}$ century). José Ignacio Lambarri Collection, Cusco. Figura 6. Pintura del Arcángel Gabriel vestido con pechera decorativa. Período Colonial (fines del siglo XVII-siglo XVIII). Colección de José Ignacio Lambarri, Cusco.

the Cuzqueño archaeologist Luis Pardo. In the accession records the piece is catalogued as Chimu; however, Pardo's commentary suggests that he believed that it was colonial in date. This suggestion is consistent with the baroquestyle angelic visage on the spout, the applique crescent lip decoration, and the curvilinear ornamental handles which served no practical purpose. The Museo Inka colonial paccha shows considerable damage with several pieces of the rim and one of the strap handles missing.

As on PC-1, a stylized zig-zag depiction of the amaru is shown on the chamber with colored glass inlaid in the serpent's body and the secondary marine elements hanging from it. A close look at the blue and green inlays reveals that they, like those in PC-1, are small fragments of colored glass, a material introduced into the New World by the Spaniards. Interestingly, there was a prehispanic tradition on the north coast of Peru of crafting ritual objects inlaid with chrysocolla, sodalite and other green and blue stones. This prehispanic tradition of inlays is well represented by the gold 
Table 1. Ceramic annular pacchas from Cusco. Tabla 1. Pacchas cerámicas de cámara anular del Cusco.

\begin{tabular}{|c|c|c|c|c|c|c|}
\hline ID & LOCATION & AGE & DIAM. & $\begin{array}{c}\text { DIAM. } \\
\text { CHAMBER }\end{array}$ & $\begin{array}{c}\text { VERTICAL } \\
\text { NECK HEIGHT }\end{array}$ & FIGURE \\
\hline PC-1 & Private Collection & Colonial & $19 \mathrm{~cm}$ & $3,5 \mathrm{~cm}$ & $11,8 \mathrm{~cm}$ & Figs. 2-3 \\
\hline MI-1 & Museo Inka & Colonial & $20 \mathrm{~cm}$ & $4,5 \mathrm{~cm}$ & $13 \mathrm{~cm}$ & Figs. 7-8 \\
\hline JVL-1 & Jaime Liévana Collection & Colonial & $27 \mathrm{~cm}$ & $4 \mathrm{~cm}$ & $13 \mathrm{~cm}$ & Figs. 9-10 \\
\hline JIL-1 & José Ignacio Lambarri Collection & Colonial & $21 \mathrm{~cm}$ & $4 \mathrm{~cm}$ & $7 \mathrm{~cm}$ & Figs. 11-12 \\
\hline MNPC-1 & Museo de la Cultura Peruana & Colonial & $19 \mathrm{~cm}$ & $5 \mathrm{~cm}$ & $9,6 \mathrm{~cm}$ & Fig. 13 \\
\hline FM-1 & Field Museum of Natural History & $19^{\text {th }}$ century & $15,5 \mathrm{~cm}$ & $3,9 \mathrm{~cm}$ & $7,7 \mathrm{~cm}$ & Figs. 14-15 \\
\hline MI-2 & Museo Inka & $19^{\text {th }}$ century & $15 \mathrm{~cm}$ & $4 \mathrm{~cm}$ & $6 \mathrm{~cm}$ & Figs. $16-18$ \\
\hline MI-3 & Museo Inka & $19^{\text {th }}$ century & $10 \mathrm{~cm}$ & $3 \mathrm{~cm}$ & $5,5 \mathrm{~cm}$ & Figs. 19-20 \\
\hline MI-4 & Museo Inka & $20^{\text {th }}$ century & $11 \mathrm{~cm}$ & $3 \mathrm{~cm}$ & $5 \mathrm{~cm}$ & Figs. 21-22 \\
\hline JIL-2 & José Ignacio Lambarri Collection & $20^{\text {th }}$ century & $20 \mathrm{~cm}$ & $5 \mathrm{~cm}$ & $6 \mathrm{~cm}$ & Fig. 23 \\
\hline CA-1 & Catherine Allen Collection & $20^{\text {th }}$ century & $12 \mathrm{~cm}$ & $2,5 \mathrm{~cm}$ & $6 \mathrm{~cm}$ & Fig. 24 \\
\hline PC-2 & Private Collection & $20^{\text {th }}$ century & $21 \mathrm{~cm}$ & $4 \mathrm{~cm}$ & $7,5 \mathrm{~cm}$ & Figs. $25-26$ \\
\hline MS-1 & Mari Solari Collection & $20^{\text {th }}$ century & $19 \mathrm{~cm}$ & $4 \mathrm{~cm}$ & $7,5 \mathrm{~cm}$ & Figs. 27-29 \\
\hline
\end{tabular}

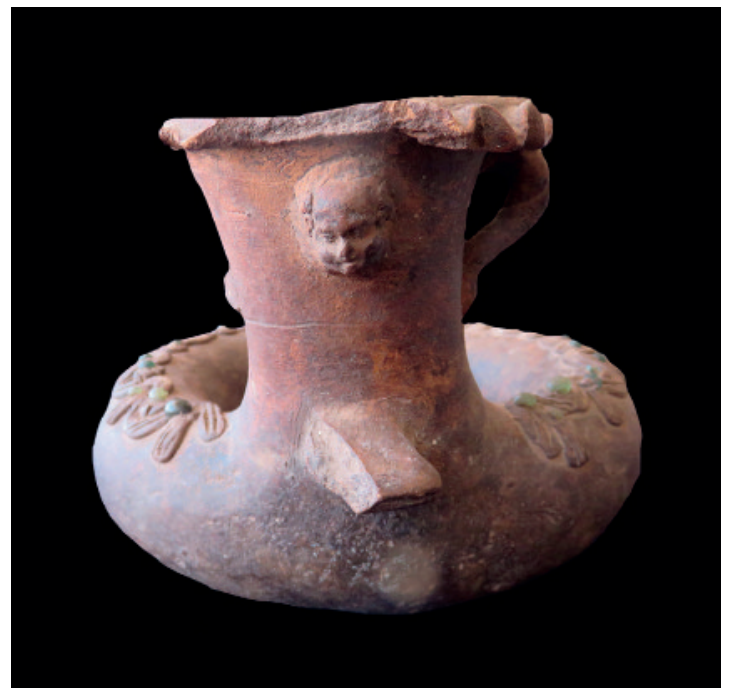

Figure 7. Ceramic annular paccha with strap handles, applique lip band and modeled cherub face (MI-1). Colonial Period, Cusco. Museo Inka, Cusco. Figura 7. Paccha cerámica de cámara anular con mangos de correa, venda de labios sobrepuesta y cara de querubin modelado (MI-1). Período Colonial, Cusco. Museo Inka, Cusco.

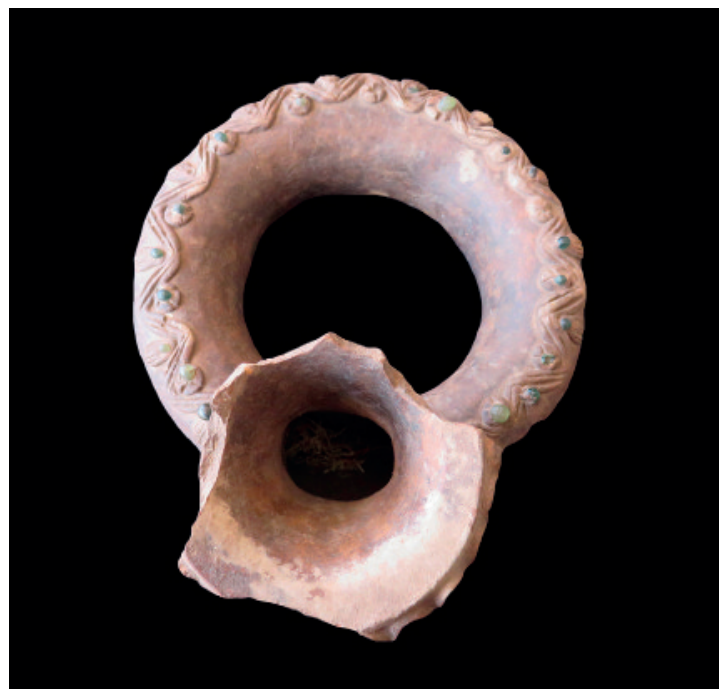

Figure 8. Ring-shaped chamber of annular paccha with image of amaru adorned with inlayed glass and stylized marine elements (MI-1). Colonial Period, Cusco. Museo Inka, Cusco. Figura 8. Cámara circular de paccha de cuerpo anular con imagen de amaru, adornada con vidrio incrustado y elementos marinos estilizados (mI-1). Período Colonial, Cusco. Museo Inka, Cusco. 
beakers and knives in the collection of the Metropolitan Museum of Art. These were crafted by artisans of the Lambayeque (or Sicán) culture around AD 1100 (Jones 1985: 230, figs. 67, 68, 75).

These semi-precious stones probably were added to the gold drinking vessel because their colors were symbolically associated with fertility and vegetation. If so, the blue and green glass fragments incorporated in PC-1 and MI- 1 would be a natural complement to the imagery of an amaru adorned with marine symbols. Sea shells were traditional offerings designed to bring rain, fertility and health. Moreover, David Blower (2000) has noted that in Ecuador the native populations in Otavalo and Salasca still use the word mullu not only for spondylus shell, but also to refer to beads of diverse colors (including blue and green). This use of the term mullu apparently dates back to colonial times (Duviols 2003: 189) and suggests a spiritual relationship between blue or green glass and spondylus shells. If so, the cosmological associations of colored glass inlays reinforced the symbolic power of the iconography on the paccha chambers.

In summary, a pair of matching colonial pacchas (PC-1 and MI-1) adopted elements of Spanish ceramic style to transform a traditional Andean ring-shaped paccha into a colonial vessel. Nonetheless, the vessel form remained essentially the same and the iconography decorating the paccha was dominated by the amaru and other Andean symbols of fertility, especially shells. This is consistent with its function as an Andean libation vessel. The strong impression made by European glass, which was both translucent and colored, appears to have led them to substitute this newly introduced material for the more traditional semi-precious stones as inlays.

A third colonial annular paccha (figs. 9 and 10) was identified in the private collection of Jaime and Vivian Liébana (JVL-1) in Lima. Jaime Liébana believed that this piece dated to the mid- $18^{\text {th }}$ century and that it came from the workshops in Santiago de Papuja near Pucara, Puno, a traditional source for Cusco's pottery (Liébana 2017, personal communication; Martínez 2009). JVL-1 was much larger than the pair of pacchas just described (table 1) and, unlike those pieces, it was decorated with ceramic glaze rather than colored glass. The overall glaze was cream-colored and green glaze was used to highlight important elements. In some spots the terracotta red-brown color of unglazed sections of the vessel remained visible. The base of the JVL-1 was left unglazed and undecorated.

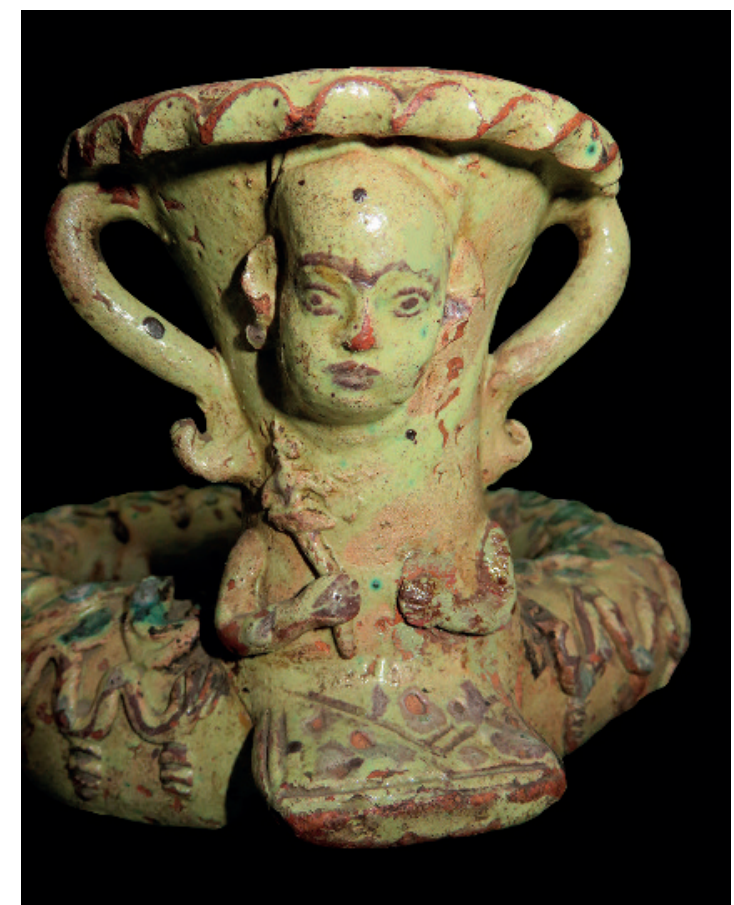

Figure 9. Glazed ceramic annular paccha with strap handles, applique lip band, and modeled cherub face and body (JVL-1). Colonial Period, Cusco. Jaime and Vivian Liébana Collection, Lima. Figura 9. Paccha cerámica vidriada con mangos de correa, venda de labios sobrepuesta y cara y cuerpo de querubín modelado (JVL-1). Periodo Colonial, Cusco. Colección de Jaime y Vivian Liébana, Lima.

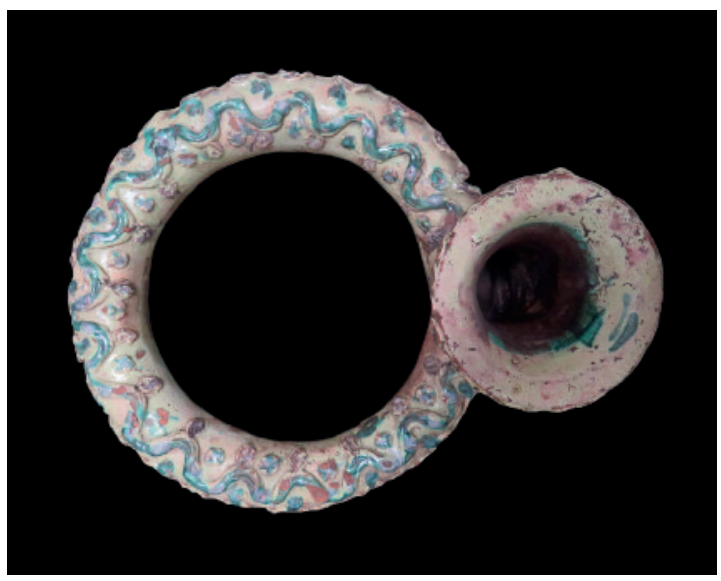

Figure 10. Ring-shaped chamber of glazed annular paccha from Cusco with image of dual amarus adorned with stylized marine elements (JVL-1). Colonial Period, Cusco. Jaime and Vivian Liébana Collection, Lima. Figura 10. Cámara circular de paccha de cuerpo anular vidriada con imagen de amarus dobles, adornada con elementos marinos estilizados (JVL-1). Período Colonial, Cusco. Colección de Jaime y Vivian Liébana, Lima. 


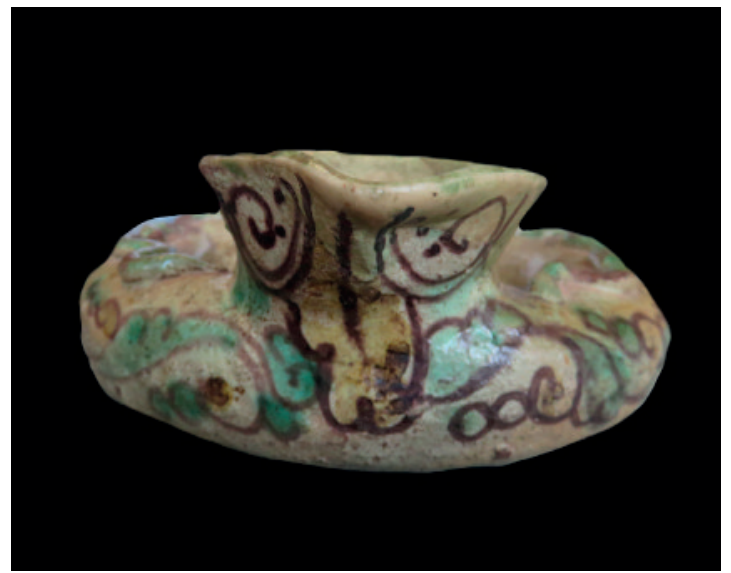

Figure 11. Glazed annular paccha with polychrome painting of vegetation. Spout has a pouring lip (JIL-1). Colonial Period, Cusco. José Ignacio Lambarri Collection, Hacienda Huayoccari, Cusco. Figura 11. Paccha de cámara anular vidriada con pintura policromática de vegetación, la boquilla tiene un labio evertido (JIL1). Periodo Colonial, Cusco. Colección de José Ignacio Lambarri, Hacienda Huayoccari, Cusco.

This remarkable paccha shares many features with PC-1 and MI-1. Like those pieces, it features an angelic face with European features shown in relief and, also like those vessels, it has an applique lip band with crescents as well as ornamental curved lateral handles attached to the spout. It also is similar in having a decorated slab projecting from below the face, perhaps representing a decorated chest ornament or bib. Unlike the matching pair of colonial pacchas, the cherubic face on the spout of JVL-1 is modeled in higher relief and at a larger scale. The upper body of the figure is shown; it has flexed arms with a scepter, staff or weapon in its right hand (fig. 9). Another difference is that the top of the ring-shaped chamber is decorated with not one but two bas-relief serpents. The bodies of these two amarus are shown in a curvilinear position rather than the more stylized geometric zig-zag patterning found on the unglazed pacchas (fig. 10). A snake painted with green glaze encircles the top of the tube-shaped chamber while a cream-colored undulating snake runs below it in a lower register. Hanging from the undulating creamcolored glazed serpent are two contrasting irregular forms, one with horizontal incisions and the other with vertical incisions. Hanging from the upper undulating green glazed serpent are comparable elements. Some appliques are painted with green glaze over vertical incisions, while those below are painted with cream-

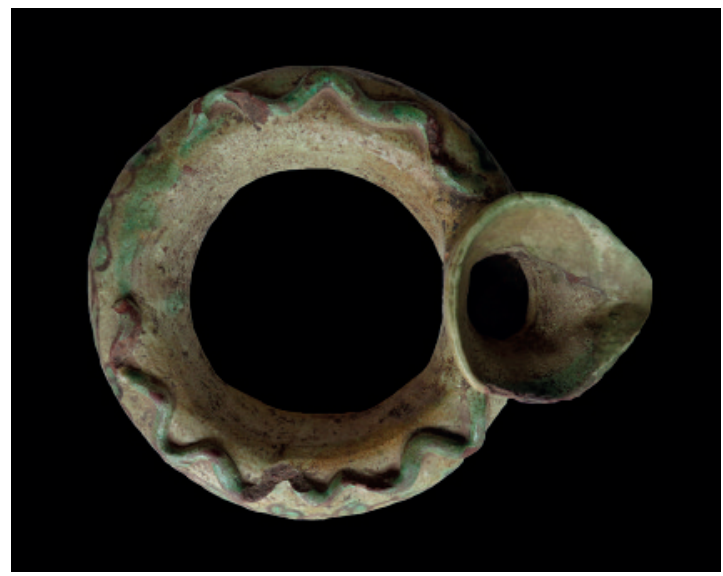

Figure 12. Ring-shaped chamber decorated with modeled dual snakes (JIL-1). Colonial Period, Cusco. José Ignacio Lambarri Collection. Hacienda Huayoccari., Cusco. Figura 12. Cámara circular decorada con serpientes duales modeladas (JIL-1). Período Colonial, Cusco. Colección de José Ignacio Lambarri. Hacienda Huayoccari, Cusco.

colored glaze over horizontal incisions. The use of glaze of contrasting colors highlights the dual nature of the objects that adorn the amarus. It is probable that these secondary elements are highly stylized versions of the marine symbols adorning the amarus on PC- 1 and MI- 1 . The shelf-like slab on JVL-1 appears at waist level rather than at chest level and it is embellished with incisions and punctations. The prominence of colored glaze on JVL-1, another innovative technology introduced to Peru by the Spanish invaders, seems to have been employed as an alternative to glass inlays on this annular paccha..

A fourth colonial annular paccha (JIL-1), also decorated with ceramic glaze, exists in the collection of José Ignacio Lambarri at the Hacienda Huayoccari in the Urubamba Valley (figs. 11 and 12). According to Lambarri, he inherited this annular paccha from his grandfather. It is unlike the colonial annular pacchas already described in many ways. It has the characteristic tubular chamber and vertical spout, but painted decoration covers the sides of the spout and the ring-shaped chamber (fig. 11). An overall cream-colored glaze covers the annular paccha but the spout and the sides of the chamber are adorned with green curvilinear motifs bordered by black lines. The decoration suggests lush vegetation with irregular forms that could be interpreted as leaves and circular shapes that could represent fruit, such as grapes. This imagery is reminiscent of colonial 


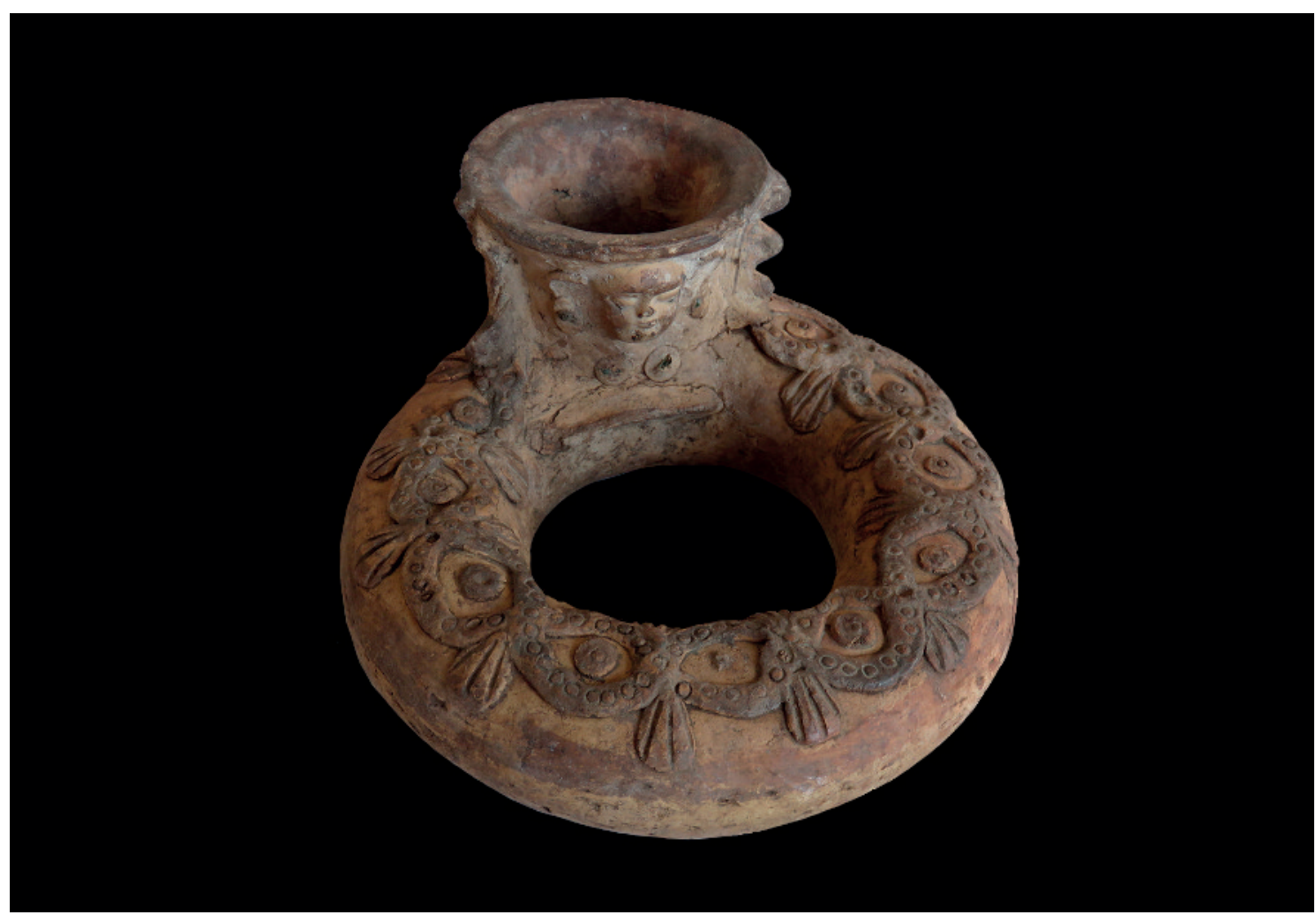

Figure 13. Ceramic annular paccha with modeled cherub wearing ear ornaments with inlayed colored glass (MNCP-1) on the spout and braided amarus and secondary elements on the ring-shaped chamber (MNCP-1). Colonial Period, MNCP, Lima. Figura 13. Paccha cerámica de cámara anular con querubín modelado usando decoraciones de orejas con vidrios de colores incrustados (MNCP-1) en la boquilla $y$ amarus trenzados y elementos secundarios sobre la cámara circular (MNCP-1). Período Colonial, MNCP, Lima.

mural painting common in the southern highlands of Cusco, Puno and Arequipa during the $18^{\text {th }}$ century. Art historians have argued that the wall paintings of luxuriant vegetation represent an Andean conflation of ideas of uku-pacha (underworld) and the Garden of Eden (Cohen Suarez 2016: 114-115). There were strong associations of the amaru with the watery underworld. The European-style depiction of abundant vegetation on the sides of the vessel can be considered as consistent with the role of annular paccha in Andean fertility rituals and its association with the amaru.

Significantly, the spout of JIL-1 is pinched at the front to facilitate pouring, a practice common in $\mathrm{Eu}-$ ropean pitchers. While the form of the spout and the glazed painting give the vessel a Hispanic appearance, JIL-1 lacks the modeled cherubic face and the applique lip band found on the other Colonial annular pacchas. More importantly, the decoration of JIL-1 is dominated by the bas-relief imagery on the top of the ring-shaped chamber that shows two curvilinear amarus painted with green glaze (fig. 12). These are shown in series covering the top of the chamber, rather than one on top of the other as in JVL-1. Unlike other colonial pacchas, there are no secondary hanging elements, and no effort is made to differentiate the snakes by color. Nonetheless the depiction of the two amarus suggests that dualistic principles continued to be materially expressed.

I encountered a fifth colonial annular paccha (MNPC1) in the collection of the Museo Nacional de la Cultura Peruana in Lima (fig. 13). This piece was accessioned into the museum's collections in 1947 by anthropologist Luis Valcarcel, who was the museum director at the time. The paccha was catalogued as coming from Cusco, the city where Valcarcel grew up. In many respects, MNPC-1 resembles the pair of unglazed annular pacchas (PC-1 and MI-1) described at the outset of this section. Like those pieces, it was made of the red-brown oxidized ware polished to a low gloss. Similar to the others, it has 
an applique angelic face on the spout, glass inlays, and bas-relief depictions of an amaru on the upper surface of the ring-shaped chamber.

However, there are some major differences between MNPC- 1 and the other two annular pacchas. First of all, the spout on MNPC-1 is positioned on the back of the paccha rather than the front. Moreover, like JIL-1, the lip of the spout is unadorned rather than featuring an applique band with crescents. The European-influenced curvilinear strap handles on PC-1, MI- 1 , and JVL-1 are absent and have been replaced with three solid triangular appendages vertically arrayed along the sides of the spout. The cherubic face is shown in typical fashion, but ears and ear ornaments are depicted. Beneath the disembodied head, two circular forms appear, possibly representing the heads of Andean shawl pins (tupus). Significantly, the colored glass inlays consist of small angular pieces of colored glass and they do not adorn the bib or the body of the amaru. Instead, they are inlaid in the ear ornaments and circular elements beneath the face. Below these is a horizontal slab that is smaller in scale than those previously discussed. It is undecorated and appears to be a vestigial element whose original meaning has been forgotten.

While the cherubic face on MNCP-1 is familiar, the bas-relief depiction of the amaru on the tubular chamber is distinctive. Two curvilinear snake-like bands intertwine with each other forming a guilloche. There are pendant ovoid shell-like elements with vertical incisions hanging from the body of the intertwined snakes, reminiscent of secondary elements from other colonial pacchas, but the round elements appear in the interstices of the braided snakes rather than in contrast to the hanging shells. Also unprecedented among the colonial pacchas, the bodies of the braided snakes on MNCP-1 are decorated with repeating stamped circles. This decorative motif has been suggested as representing the markings of the anaconda, the giant riverine snake of the tropical forest (Burger 1992: 153, fig. 142), and there is an ancient tradition of decorating serpents with circular motifs going back to Chavin times. These same small stamped circles decorate the secondary circular elements in the interstices. In another innovation, MNCP-1 has a band of dark red colored slip (8-12 mm wide) that encircles the tubular chamber and a patch of white slip covering the back of the spout. In my sample of colonial pacchas, this is the first to use colored slip painting as opposed to colored ceramic glaze as a decorative technique.
Several of the unprecedented features that appear on MNCP-1 also are found on the annular pacchas dating to the $19^{\text {th }}$ century. This suggests that the Museo Nacional de la Cultura Peruana paccha was produced in the late Colonial Period after the other colonial annular pacchas in the sample.

\section{ANNULAR PACCHAS OF THE $19^{\text {TH }}$ CENTURY FROM CUSCO}

Three annular pacchas were located that can be dated to the $19^{\text {th }}$ century. Of the three, the annular paccha whose age is best established is at the Field Museum of Natural History in Chicago (figs. 14 and 15). This paccha, FM-1, was part of the collection that was put together beginning in 1823 by Emilio Montes. A hacienda owner in Apurimac and former mayor of Cusco, Montes read widely and developed one of the largest collections in Cusco (Gänger 2014: 66-68). He brought his collection to the United States for display at the 1893 World Columbian Exposition in Chicago and when the Exposition closed, it was purchased by the Field Museum of Natural History. Montes was fascinated with antiquities and he produced a catalog with commentary that described the contents of his collection. In her study of the Cuzqueño collectors and collections, Steffanie Gänger summarizes a passage from Montes's catalog in which he refers to a vessel decorated with snakes used for the sacrificial spilling of liquids. Montes notes that this vessel illustrates how certain types of material culture in his collection were analogous to those in use among contemporary local peasants. He states that the "Indians" still used similar ritual vessels in their festivities "to drink the aka [chicha], through a barley or wheat straw" (Gänger 2014: 78). This statement confirms the ceremonial function of annular pacchas and the fact that they still were being used by indigenous communities in the $19^{\text {th }}$ century. It also shows how Montes used his ethnographic knowledge to interpret the pieces in his collection.

Compared to the annular pacchas described thus far, FM-1 is smaller and of coarser fabrication (table 1). It lacks evidence of ceramic glaze, slip painting or glass inlays. As was the case of the MNCP-1 paccha, its spout is located at the rear of the vessel and has straight rather than concave sides. The spout is attached to the ring-shaped chamber at an oblique angle rather than the characteristic vertical position (fig. 15). It 


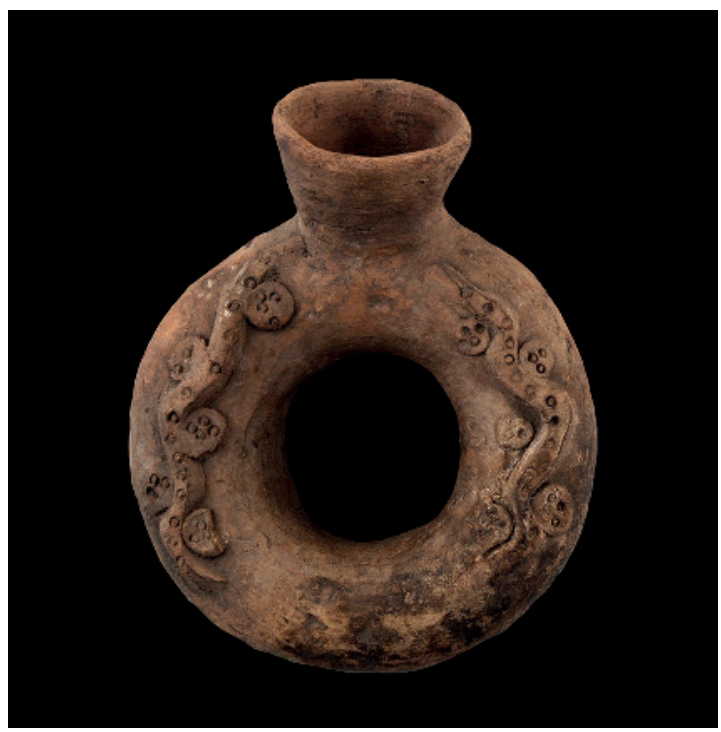

Figure 14. Coarsely made annular paccha with applique amarus and circular elements decorating the ring-shaped chamber (FM-1), Cusco. Field Museum of Natural History, Chicago, $19^{\text {th }}$ century. Figura 14. Paccha de cámara anular elaborada de manera tosca con amarus de apliqué y elementos circulares decorando la cámara con forma circular (FM-1), Cusco. Field Museum of Natural History, Chicago, siglo XIX.

also lacks lateral adornments such as strap handles or modeled decoration. The top of the tubular chamber, however, is adorned by two undulating serpent motifs each with a row of cane stamping along their bodies. Besides the dual amarus, there are also small circular elements similar to those in the interstices of MNCP-1, but decorated with three or four small stamped circles each rather than one. The spout and sides of the paccha are left unadorned. The presence of curvilinear snakes with cane stamping on their bodies links this paccha with the annular paccha from the Museo Nacional de la Cultura Peruana collection (fig. 13).

The other two $19^{\text {th }}$ century pacchas belong to the Museo Inka. Luis Pardo accessioned them in 1941 and recorded that they come from Cusco. The first of these (MI-2) is another small and coarsely made annular paccha with uneven sides and a complete absence of polishing or painting (figs. 16-18). Like the Montes paccha from the Field Museum, MI-2's spout is situated at the rear and has straight sides. The paccha is so poorly made that the lips of its spout are uneven. Like FM-1, it features a pair of snakes in bas-relief with abundant use of small cane stamping decorating their bodies (fig. 18). These stylized serpents resemble those on FM-1, but unlike

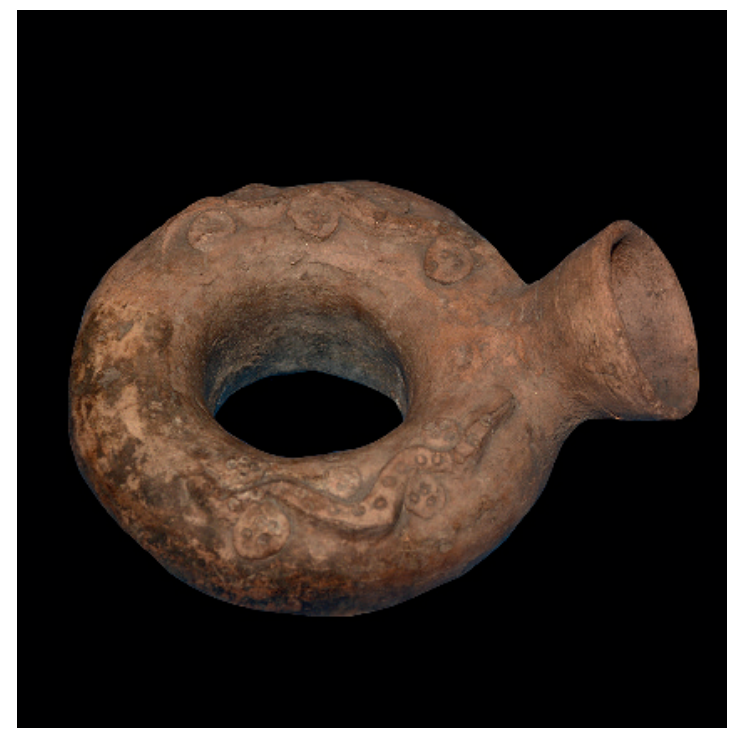

Figure 15. Ceramic annular paccha with amarus (FM-1), Cusco. Note oblique angle of the spout. Field Museum of Natural History, Chicago, $19^{\text {th }}$ century. Figura 15. Paccha cerámica de cámara anular con amarus (FM-1), Cusco. Se observa el ángulo oblicuo de la boquilla. Field Museum of Natural History, Chicago, siglo XIX.

those on FM-1, the two snakes are shown as creeping up the sides of the spout (fig. 17). On MI-2 the cane stamping extends beyond the amarus and covers the upper section of the tubular chamber and the spout (fig. 16).

The other annular paccha (MI-3) from the Museo Inka, which dates to the $19^{\text {th }}$ century, is better made than the other two $19^{\text {th }}$ century annular pacchas. It is polished and its exterior surface is even (figs. 19 and 20). As with MI-2 and FM-1, its spout is located at the rear of the annular paccha and it lacks glazing and glass inlays. A dark red slip was applied unevenly before it was burnished, and this use of red slip is shared with MNCP1. The spout was left undecorated as were the sides of the ring-shaped chamber. Decoration is limited to the upper surface of the tubular chamber and it consists of a coarser and less precise version of the bas-relief braided amarus found on the paccha from the Museo Nacional de la Cultura Peruana (fig. 13). As in MNCP-1, the dual snakes are shown intertwined with a line of cane stamping along their bodies and round elements with canestamping appear in the interstices of the braided snakes (fig. 20). One important difference, however, is that the pendant ovoids are incised with diagonal rather than vertical lines, suggesting leaves rather than spondylus 

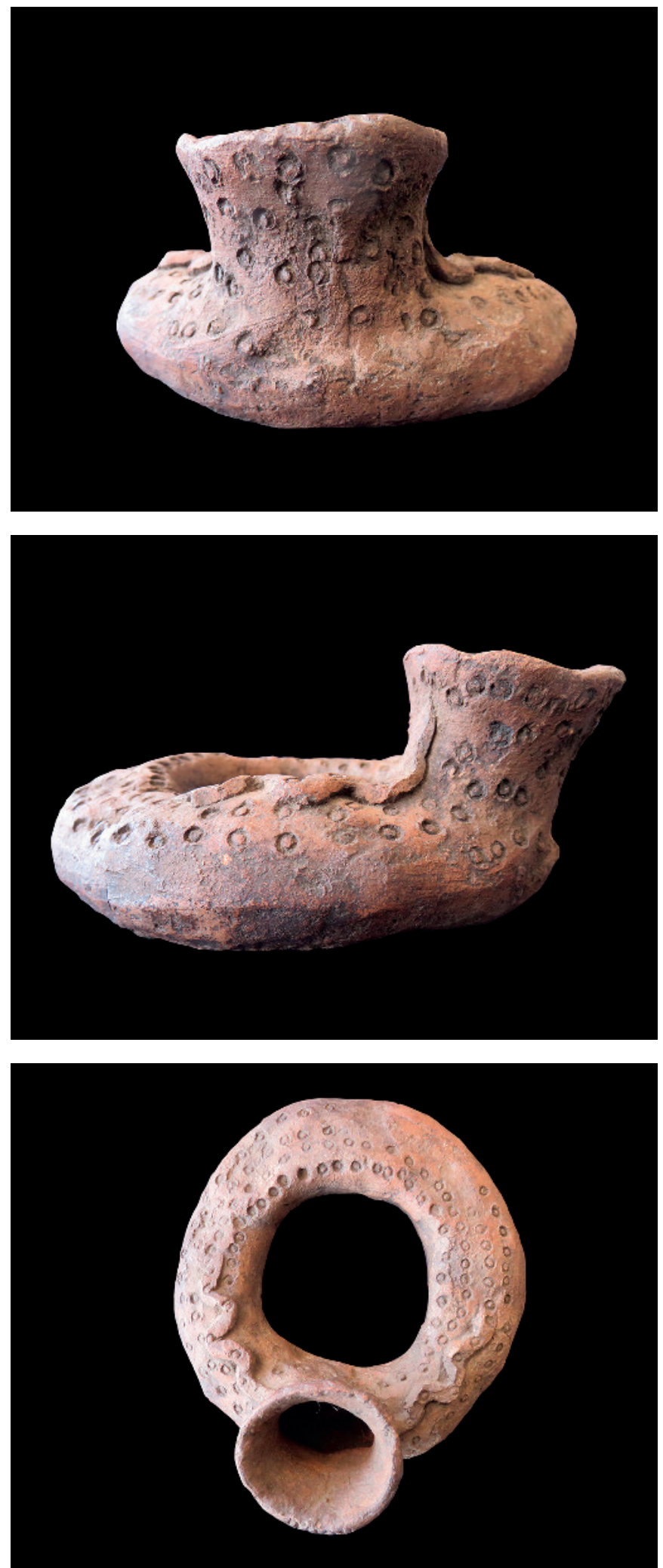

Figure 16. Ceramic annular paccha with small circles covering the back of the spout and sides of the chamber (MI-2). Museo Inka, Cusco, 19 th $^{\text {th }}$ century. Figura 16. Paccha cerámica de cámara anular con pequeños círculos que cubren la parte posterior de la boquilla y los lados de la cámara (MI-2). Museo Inka, Cusco, siglo XIX.

Figure 17. Ceramic annular paccha with applique amarus on the cane stamped ring-shaped chamber shown climbing the sides of the spout (MI-2). Museo Inka, Cusco, $19^{\text {th }}$ century. Figura 17. Paccha cerámica de cámara anular con amarus sobrepuestos que son representados escalando los costados de la boquilla sobre la cámara circular con timbres de caña (MI-2). Museo Inka, Cusco, siglo XIX.

Figure 18. Coarsely-made ceramic annular paccha with sinuous applique amarus on the cane stamped ring-shaped chamber (MI-2). Museo Inka, Cusco, $19^{\text {th }}$ century. Figura 18. Paccha de cámara anular elaborada de manera tosca con amarus serpenteantes de apliqué sobre la cámara circular con timbres de caña (MI-2). Museo Inka, Cusco, siglo XIX. 


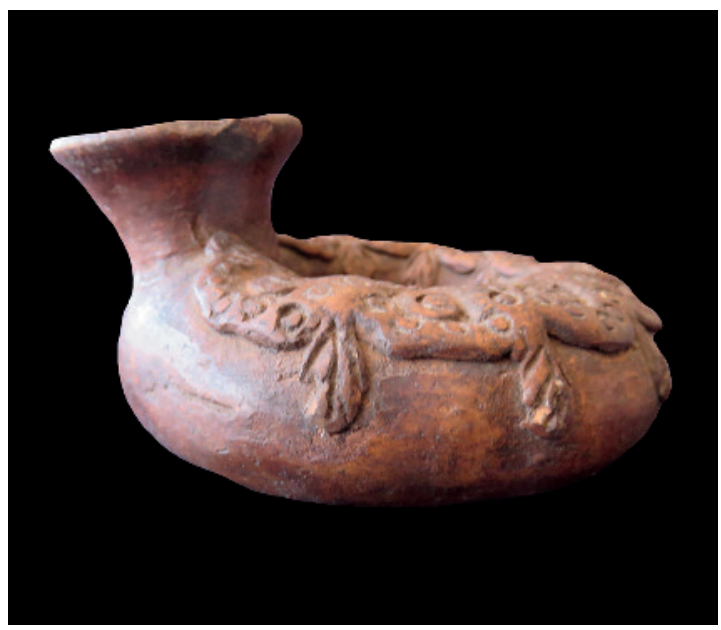

Figure 19. Ceramic annular paccha with braided amarus adorned with secondary elements (MI-3). Museo Inka, Cusco, $19^{\text {th }}$ century. Figura 19. Paccha cerámica de cámara anular con amarus trenzados, decorados con elementos secundarios (мI-3). Museo Inka, Cusco, siglo XIX.

shells (fig. 19). While there are similarities between MI-3 and MNCP-1, the absence of the cherubic face and glass inlays is significant and is consistent with the evidence for a later date than the MNCP-1 paccha. A final observation is that this annular paccha is smaller than the colonial pacchas discussed and is much closer in size to the other two $19^{\text {th }}$ century pacchas than the five colonial pacchas (table 1). For example, MI-3 is only half the size of the annular paccha in the Liébana Collection.

\section{$20^{\text {TH }}$ CENTURY ANNULAR PACCHAS FROM CUSCO}

Five annular pacchas can be tentatively assigned to the $20^{\text {th }}$ century. Like the $19^{\text {th }}$ century pacchas, all have their spout or spouts located at the rear of the vessel. In contrast to the colonial and $19^{\text {th }}$ century annular pacchas, most have an applique modeled creature depicted on the front of the ring-shaped chamber. One of these annular pacchas was accessioned in 1947, but the other four were acquired in Pisac and in other markets in the Cusco area during the final decades of the 20th century. While there is considerable continuity with the annular pacchas from colonial and $19^{\text {th }}$ century times, there are also many unknown features that appear for the first time on the $20^{\text {th }}$ century examples.

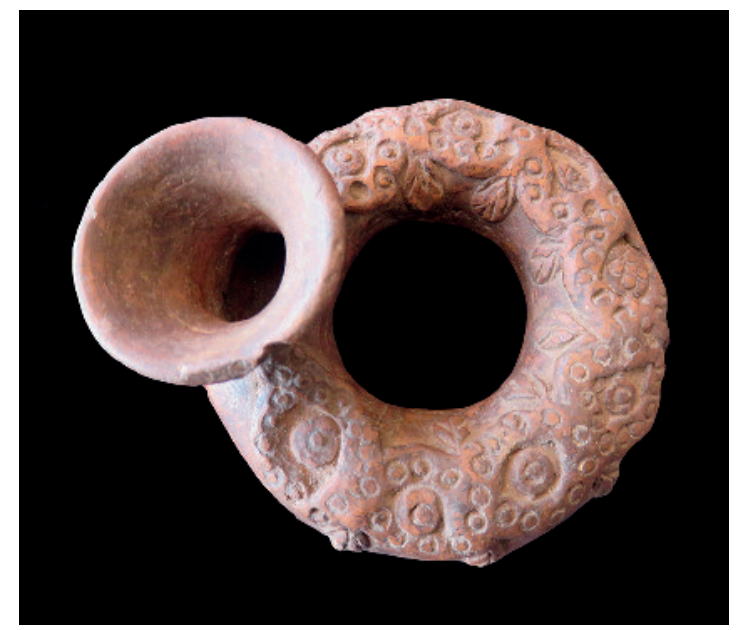

Figure 20. Annular paccha with braided amarus covered with cane stamping and adorned with stylized secondary elements (MI-3). Museo Inka, Cusco, $19^{\text {th }}$ century. Figura 20. Paccha cerámica de cámara anular con amarus trenzados cubierta con timbre de caña $y$ adornada con elementos secundarios estilizados (MI-3). Museo Inka, Cusco, siglo XIX.

Probably the oldest of the $20^{\text {th }}$ century pacchas discussed here is the painted paccha (MI-4) that was accessioned to the Museo Inka in the mid- $20^{\text {th }}$ century. The current director of the museum, Edith Mercado, and its collections manager, Rosana Abril, believe that this annular paccha is ethnographic and dates to the Republican Period (1821-present). However, it does not resemble the three $19^{\text {th }}$ century examples described here, and an early $20^{\text {th }}$ century date seems a more likely possibility. The vessel is crudely made, and its surface was left uneven without evidence of polishing (figs. 21 and 22). A cream-colored clay slip covers the entire vessel except for the underside, and decorative details were added using a dark red slip paint. A short irregular spout is situated at the back of the MI- 4 and a stylized zoomorphic solid appliqué head appears on the front of the paccha (fig. 21). The modeled applique head has ears and a flattened snout. I speculate that it represents the head of the amaru. The ring-shape of the chamber conveys the form of the serpent's body and 13 circles painted in red slip paint represent the dark markings of the anaconda, the reptile associated with the amaru. Two strap handles with a curved form are attached to the top of the ring-shaped chamber perhaps suggesting the undulating body of this mythical riverine creature (fig. 22). The strap handles, appliqué stylized animal head, and painted circular body markings are features 


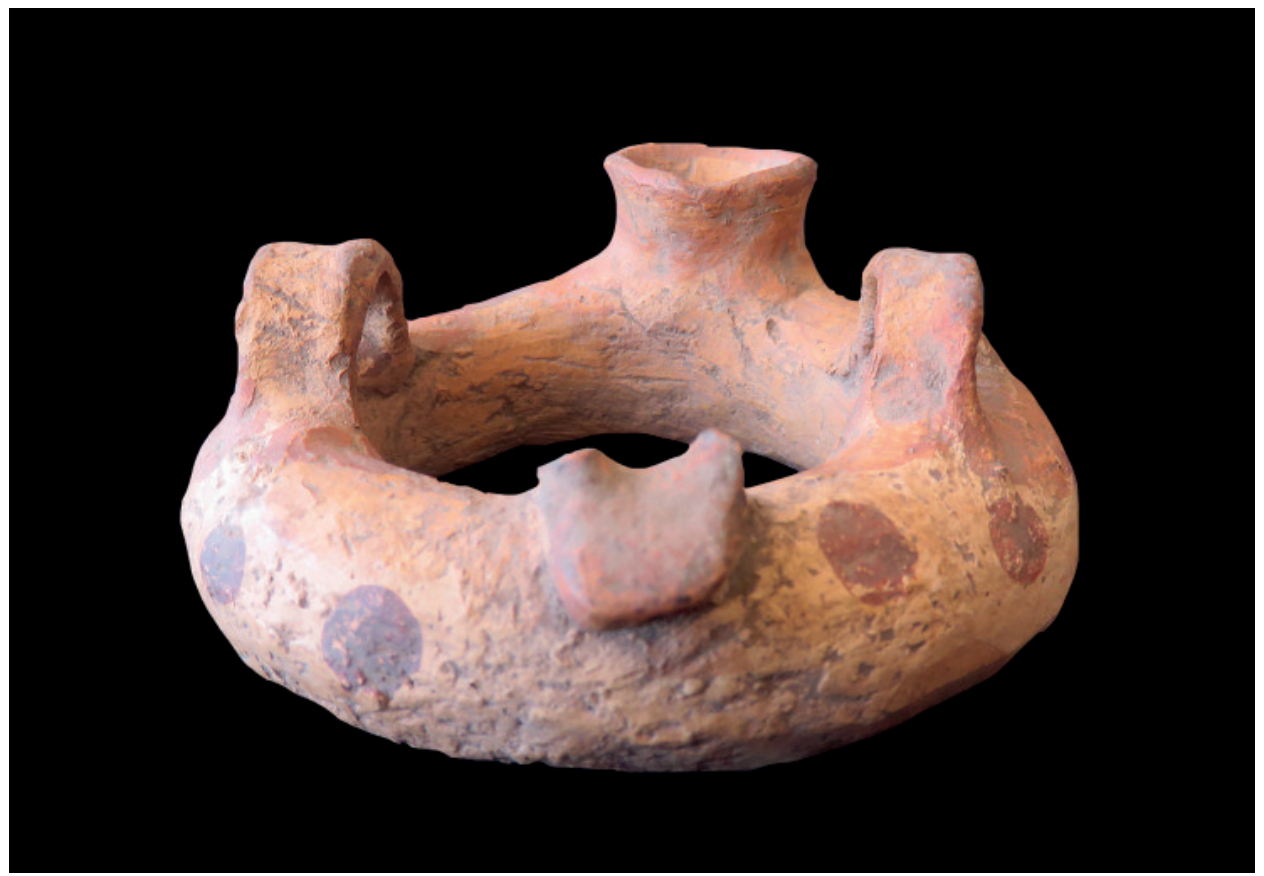

Figure 21. Coarsely-made annular paccha covered with painting augmented by red painted circles. The paccha features an applique zoomorphic element and strap handles (MI-4). Museo Inka, Cusco, $20^{\text {th }}$ century. Figura 21. Paccha de cámara anular elaborada de manera tosca con cubierta de pintura, intensificada con círculos de pintura roja. La paccha incluye un elemento zoomórfico de apliqué y mangos de correa (MI-4). Museo Inka, Cusco, siglo XX.

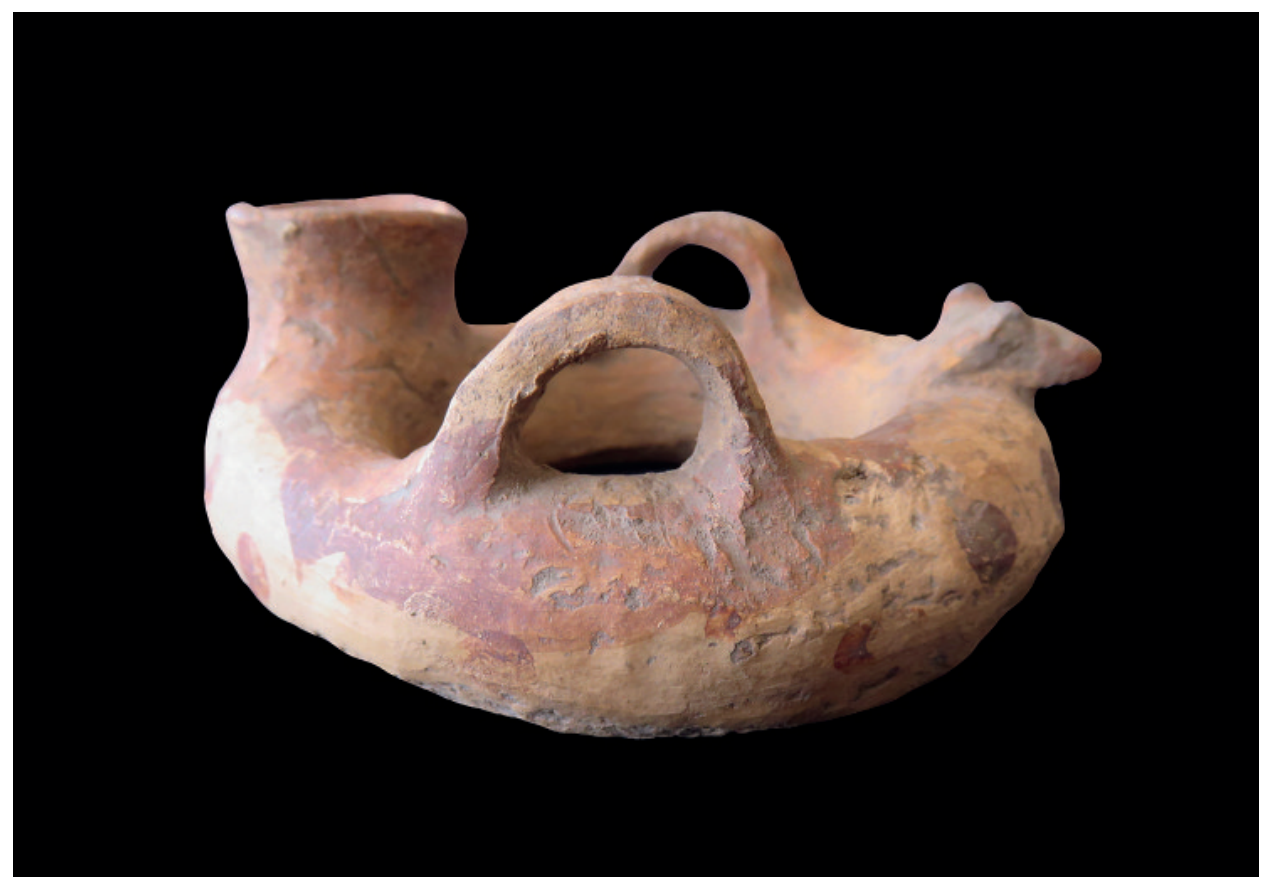

Figure 22. Annular paccha with white slip painting and red spots. The front of the paccha features a zoomorphic element (MI-4). Museo Inka, Cusco, $20^{\text {th }}$ century. Figura 22. Paccha de cámara anular con pintura de engobe blanca y puntos rojos. La sección frontal de la paccha incluye un elemento zoomórfico (MI-4). Museo Inka, Cusco, siglo XX. 


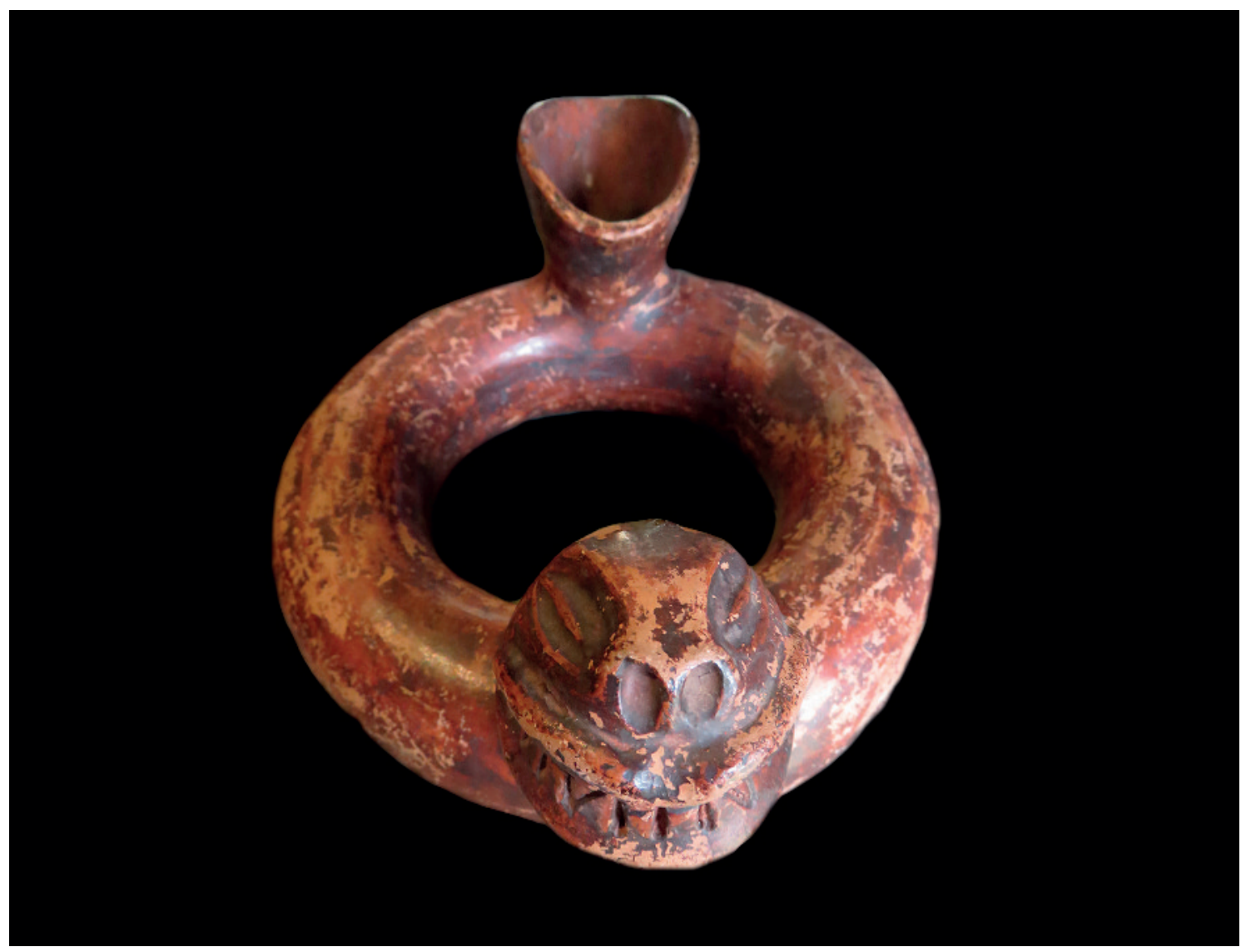

Figure 23. Red slipped annular paccha with an ovoid spout and a modeled amaru on the front of the vessel (JIL-2). José Ignacio Lambarri Collection, Hacienda Huayoccari. Cusco, $20^{\text {th }}$ century. Figura 23. Paccha de cámara anular de engobe rojo con boquilla ovoide $y$ un amaru modelado en la parte frontal de la vasija (JIL-2). Colección de José Ignacio Lambarri, Hacienda Huayoccari. Cusco, siglo Xx.

unprecedented among the colonial and $19^{\text {th }}$ century annular pacchas of Cusco.

A second $20^{\text {th }}$ century paccha (JIL-2) was encountered in the Lambarri collection. The piece was purchased in the 1990s in Cusco's flea market, popularly known as the Barratillo. Lambarri believed that the piece was ethnographic and relatively modern, perhaps dating to the second half of the $20^{\text {th }}$ century. JIL- 2 has an uneven red slip (fig. 23) and is polished to a low gloss. Situated at the back of the vessel, its spout is oval rather than circular in form and slants downward to facilitate the pouring of the liquid. On the front of the tubular chamber is a hollow modeled feline or cat-snake head. The face has coffee bean shaped eyes, two broad nostrils and a large set of teeth with interlocking fangs. There are damaged areas on the sides of the head where applique ears were probably once attached but have been broken off. As with $\mathrm{MI}-4$, the ring-shaped chamber acts as the body of the serpent terminating in the modeled head of the amaru. While JIL-2 shares the use of slip paint with MI-4, it lacks cream-colored slip painting and does not show the circular markings of the amaru.

The third $20^{\text {th }}$ century annular paccha $(\mathrm{CA}-1)$ was purchased by the ethnographer Catherine Allen in the Pisac open-air market during the 1970s (fig. 24). Fluent in Quechua and knowledgeable about highland Cusco culture, Allen is confident that this paccha was produced for making libations (tinka), probably to ensure the wellbeing of the herds that graze in the high grasslands nearby rather than for tourist consumption (Catherine Allen personal communication). Unlike many of the annular pacchas discussed here, this vessel is undamaged and appears to have never been used. It is polished unevenly and the spout, as in the other examples, is undecorated 


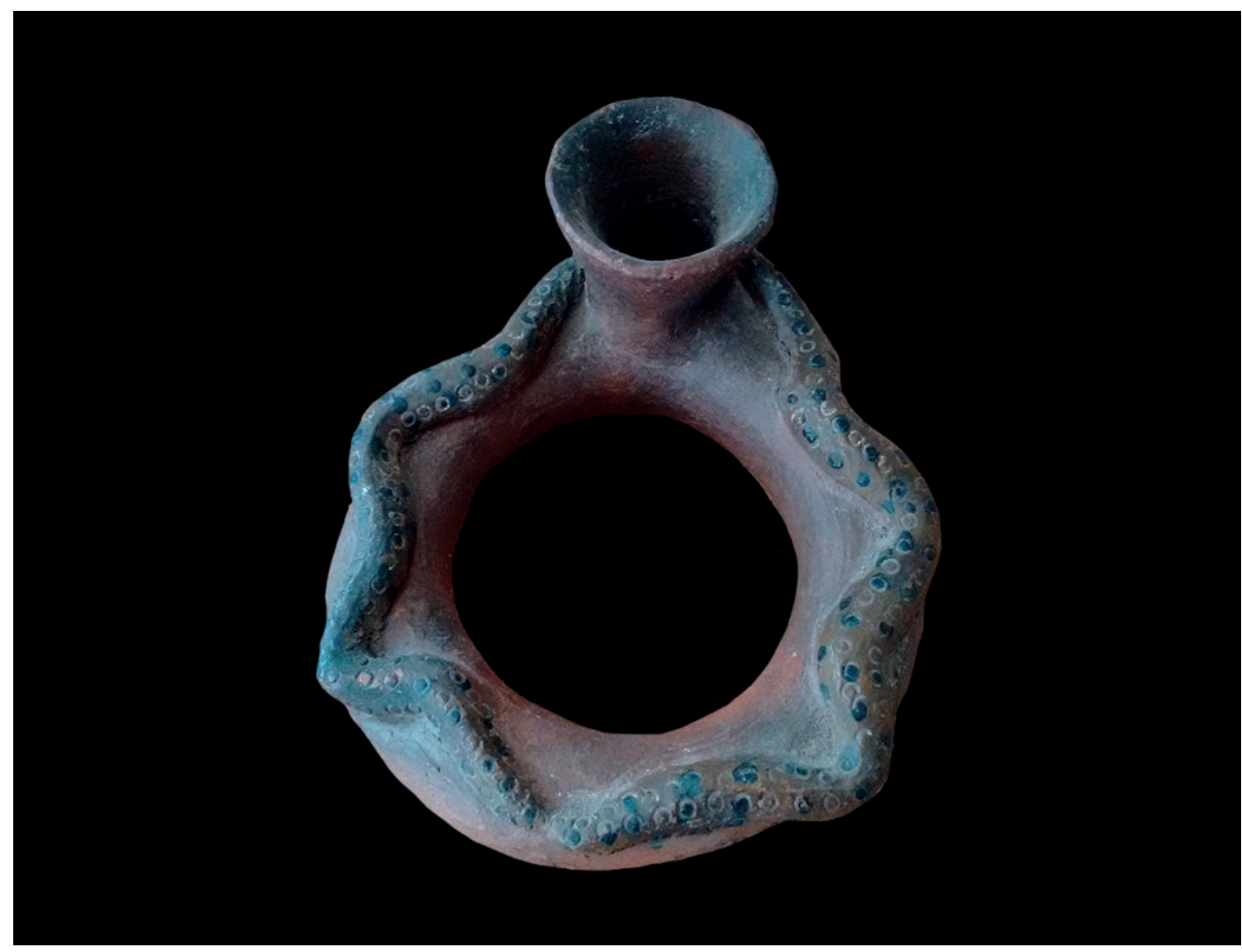

Figure 24. Small annular paccha with modeled amarus covered with cane stamping (CA-1). Catherine Allen Collection, Washington DC. Cusco, $20^{\text {th }}$ century. Figura 24. Paccha pequeña de cámara anular con amarus modelados cubiertos de sellos de caña (CA-1). Colección de Catherine Allen, Washington DC. Cusco, siglo XX.

and situated at the back of the paccha. Small in size (table 1), CA-1 is unevenly covered with a red pigmented slip; decorative details were modeled in bas-relief and then highlighted using a black slip paint. In what appears to be a conservative element, the top of the annular chamber of CA-1 is decorated with two applique snakes. The markings on these serpents are shown by small stamped circles arranged in rows. An intentional effort was made to show one of the snakes as red and the other as black, thus suggesting the dual nature of the pair. In terms of the prominence of applique snakes decorated with stamped circular markings, CA-1 is reminiscent of the pacchas dated to the $19^{\text {th }}$ century, but the use of overall red slip painting and the quality of its production is consistent with the late $20^{\text {th }}$ century date favored here.

The fourth annular paccha (PC-2) identified as $20^{\text {th }}$ century was purchased in the Pisac market in the early 1990s by an anonymous private collector. It is a large and well-made vessel with high relief modeling and slip painting. At some point during its life history, PC-2 cracked and was then repaired using a black tar-like adhesive that extends from the bottom of the ring-shaped chamber to the lip of one of the spouts (figs. 25 and 26). This damage suggests that the vessel was used in rituals and was valued enough to justify repairing it. Among the features not previously observed on other annular pacchas is the presence of three spouts rather than the traditional single spout. Despite this innovation, the spouts are positioned at the rear of the annular paccha, as has been the case since the19th century. The central spout is wider $(5,5 \mathrm{~cm}$ vs. $4,5 \mathrm{~cm})$ and slightly taller $(4 \mathrm{~cm})$ than the flanking spouts. The brown oxidized chamber of PC-2 was polished to a smooth matte surface and a set of fine-line motifs in dark red paint was painted on its 


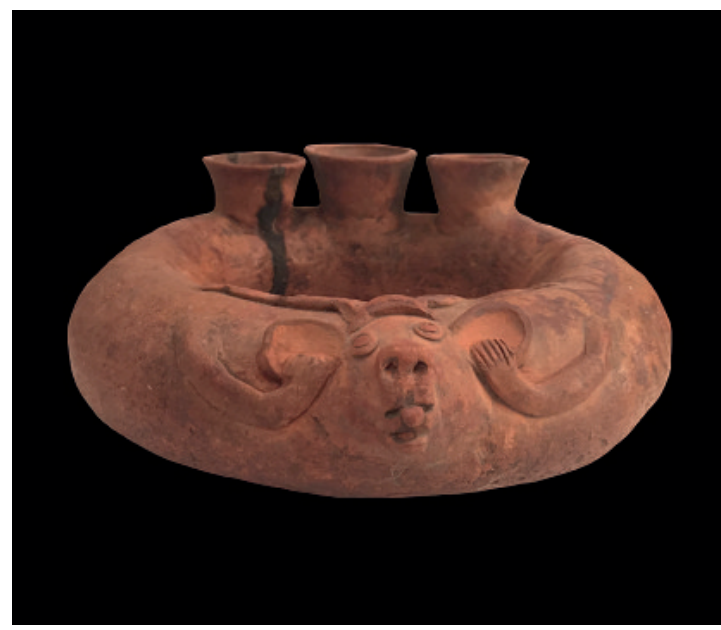

Figure 25. Annular paccha with three spouts and a modeled camelid head with ears held by anthropomorphic hands (PC-2). Anonymous private collection. Cusco, $20^{\text {th }}$ century. Figura 25. Paccha de cámara anular con tres boquillas y una cabeza modelada de camélido con orejas sostenida por manos antropomórficas (PC-2). Colección privada anónima. Cusco, siglo Xx.

surface (fig. 26). These designs include circles, triangles and rectangles with pendant lines and circular punctations. Reminiscent of Andean textile designs, these are arrayed in two horizontal rows flanking the applique modeled zoomorphic head decorating the front of the vessel. They are better preserved on the proper left of the vessel. In this zone seven design motifs are visible in the upper row and five in the lower. In addition, three triangular motifs filled with punctations were painted below the spouts. While this type of decoration does not appear on other annular pacchas, red pigmented slip painting is common on the $20^{\text {th }}$ century pacchas.

At first blush, the complex modeled zoomorphic image and associated elements on the front of PC-2 was difficult to identify, but discussions with colleagues at the 2019 Interdisciplinary Seminar in Pisac, organized by the PUCP's Program of Andean Studies, produced a plausible interpretation. The central face with its open mouth, protruding tongue, prominent nostrils, round open eyes and large projecting ears was recognized as a representation of a llama head (fig. 25). It was suggested that the anthropomorphic arms and hands that grasp the ears were reminiscent of the way in which pastoralists hold the ears of their herd animals in order to pierce

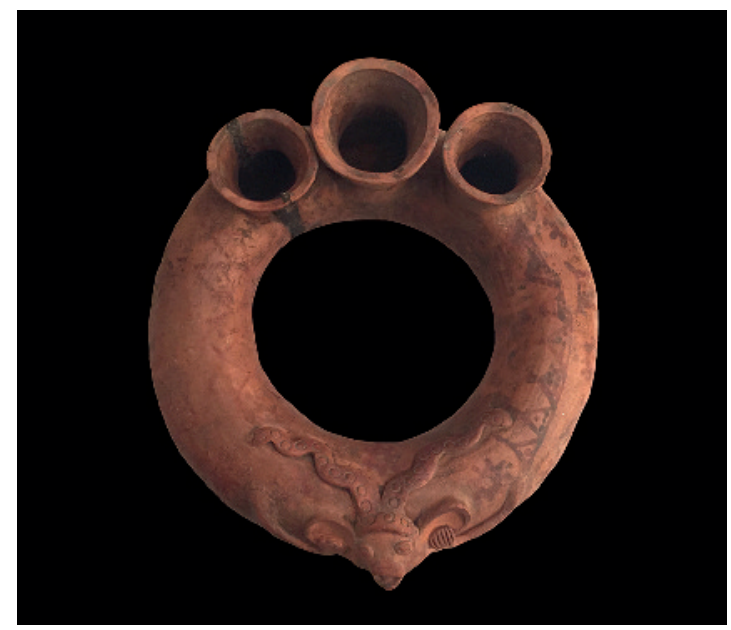

Figure 26. Decoration of the ring-shaped chamber of the annular paccha with red painted symbols and a pair of amarus attached to head of the modeled camelid (PC-2). Note the use of black tar-like substance for repair. Anonymous private collection. Cusco, $20^{\text {th }}$ century. Figura 26. Decoración de la cámara circular de la paccha de cámara anular con símbolos de pintura roja y un par de amarus unidos a la cabeza del camélido modelado (PC-2). Se puede observar una sustancia parecida al alquitrán usada para reparación. Colección privada anónima. Cusco, siglo Xx.

their ears and adorn them with bright colored ornaments during the seasonal festivities for the reproduction of the herds. Significantly, the anthropomorphic arms and hands are shown as coming from an individual that is not visible. On the top of the modeled head of the camelid is a cap decorated with small cane stamped circles. Flowing from it are dual snakes or amarus (fig. 26). These applique snakes extend in opposing directions and their sinuous bodies are covered with stamped circles. While these elements initially were thought to be the antlers of a deer, once the imagery is disentangled it becomes clear that they are simply a stylized version of the dual amarus common on Cusco annular pacchas since colonial times.

The fifth and final $20^{\text {th }}$ century annular paccha (Ms-1) from Cusco to be discussed here comes from the personal collection of Mari Solari, a well-known specialist in Andean "arte popular" (figs. 27-29). Solari acquired the annular paccha in Cusco in the 1980s or 1990 s but remembers little about the circumstances. She assumed that it was a modern piece of ethnographic interest. Ms- 1 is large and fairly well-made, and it resembles PC-2 in having three spouts in the rear of the vessel with the central one being taller and larger in 

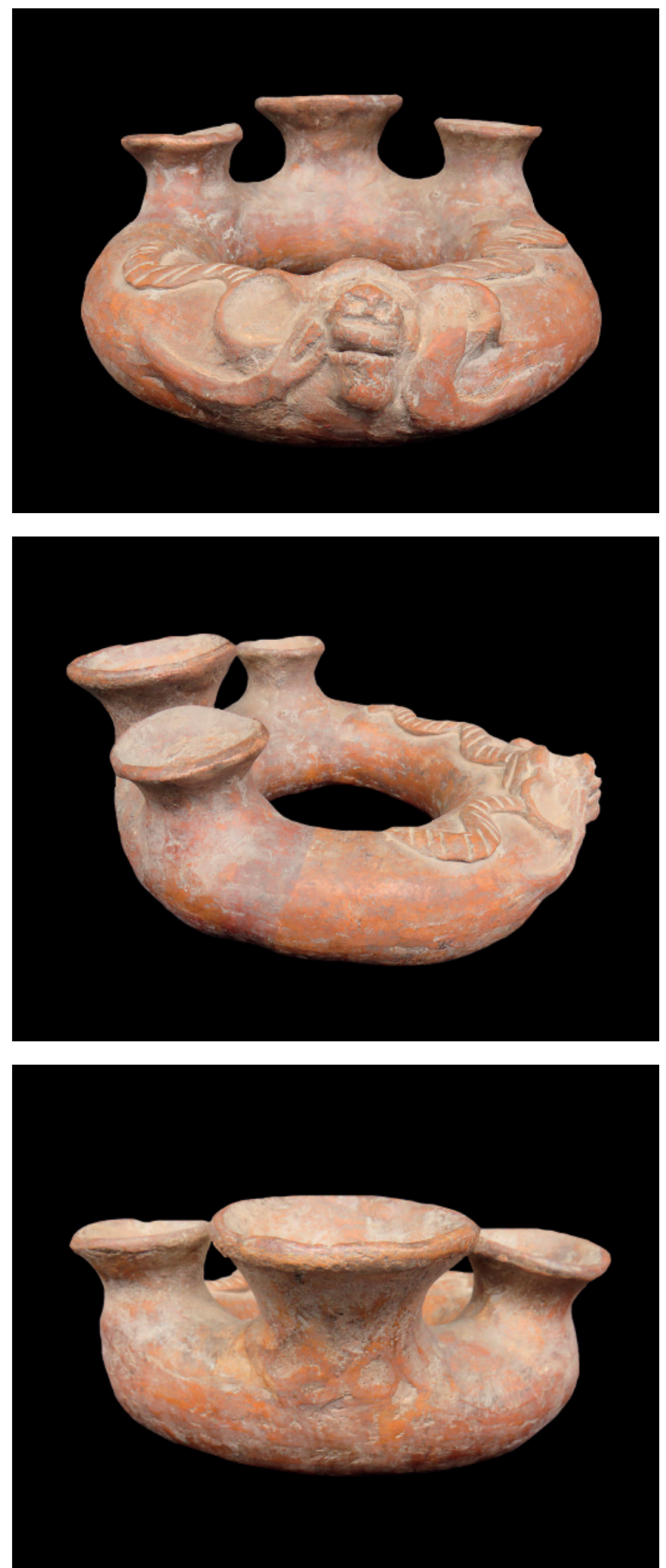

Figure 27. Annular paccha with three spouts and a modeled camelid head with ears held by anthropomorphic hands (MS-1). Mari Solari Collection, Lima. Cusco, $20^{\text {th }}$ century. Figura 27. Paccha de cámara anular con tres boquillas y una cabeza modelada de camélido con orejas sostenida por manos antropomórficas (MS-1). Colección de Mari Solari, Lima. Cusco, siglo XX.

Figure 28. Annular paccha with three spouts. Stylized amarus with diagonal incisions attached to a modeled camelid head (MS-1). Mari Solari Collection, Lima. Cusco, $20^{\text {th }}$ century. Figura 28. Paccha de cámara anular con tres boquillas. Amarus estilizados con incisiones diagonales unidas a la cabeza de camélido modelada (MS-1). Colección de Mari Solari, Lima. Cusco, siglo XX.

Figure 29. The rear side of Ms-1 adorned by three circular depressions (MS-1). Mari Solari Collection, Lima. Cusco, $20^{\text {th }}$ century. Figura 29. La parte trasera de MS-1 adornada por tres depresiones circulares (MS-1). Colección Mari Solari, Lima. Cusco, siglo Xx. 
diameter. Like PC-2, the front of the Solari paccha has a modeled applique zoomorphic face with large ears held by anthropomorphic hands. There are some differences between the modeled images on MS- 1 and PC- 2 such as the closed mouth and absence of a protruding tongue on the Solari piece, but the interpretation of the image as a camelid with its ears being adorned suggested for PC-2 is also a plausible explanation for Ms-1. In the case of the Solari annular paccha, there is a plain cap on the camelid head and attached to it are two curvilinear forms arrayed in opposing directions. Given the corpus of annular pacchas, these can be identified as highly stylized versions of the dual amarus (fig. 28). This conclusion is based on their snake-like shape, sinuous form, and their location on the upper surface of the ring-shaped chamber. However, the sc- 1 amarus are covered with incised diagonal lines rather than stamped circles. One final observation on Ms-1 is that on the back of vessel, beneath the spouts, there is an odd bas-relief design of two circles (fig. 29). There are traces of a red slip zone outlined by fine thin black lines around the spouts. The presence of this slip painting is one more feature that links this piece to other $20^{\text {th }}$ century pacchas.

\section{DISCUSSION}

Pacchas, like keros, were important ritual vessels whose roots lie deep in Andean prehistory. As specialized vessels produced for making libations in religious rituals, they served as a medium of expression for elements of prehispanic cosmology in the Andes long after the Spanish conquest, at the same time reflecting the complex changes that occurred in the ensuing centuries.

In this article, I have focused on a sub-class of ceramic pacchas from Cusco that is distinguished by its ring-shaped chamber and short vertical spout. This impractical but symbolic shape forced maize beer (chicha, $a k a$ or $a j s a$ ) through the circular chamber before it was poured into the earth as a gift to the Pachamama and the other supernatural forces that influence the well-being of the crops and/or herds. The circulation of liquids in annular pacchas quite literally mimics that aspect of Andean cosmovision modeling the journey of moisture from the celestial sphere through the mountains, valleys and springs into the sea and then back again. The analysis of post-Conquest annular pacchas has demonstrated that annular pacchas survived as a potent symbol and valued ritual tool for Andean people from 1532 to the $20^{\text {th }}$ century despite campaigns by the Roman Catholic church and the Pentecostal clergy to eliminate traditional Andean religious thought and practice.

When viewing post-Conquest annular pacchas as part of a tradition spanning more than four centuries, I am impressed by the cultural persistence that they manifest. There is evidence of a degree of artistic and religious survival not contemplated by art historian George Kubler, which belies his belief that indigenous religious art ended with the Spanish conquest. As illustrated in this article, the form of annular pacchas, which is highly symbolic, remained largely unchanged from colonial times to the present. The continuity in its form implies that its function as an Andean ritual vessel for libations also survived. This is true as well for the motifs that decorated these objects. As illustrated, the adornment of the annular pacchas is dominated by the representation of the amaru from the $16^{\text {th }}$ to the $20^{\text {th }}$ century. The amaru was a mythical snake that was associated with water and its circulation from the underworld to the sky. While the amaru was supplemented by water-related motifs of marine shells or lush vegetation in the Colonial Period, these secondary elements fall away during the $19^{\text {th }}$ century leaving the amaru as the central perduring motif. This continues in the $20^{\text {th }}$ century and this unbroken continuity of annular pacchas and their imagery cannot be interpreted as an example of Kubler's disjunction. On the contrary, the survival of annular pacchas is the result of continuity in Andean ritual practice and religious thought during the centuries following the Spanish conquest.

Nonetheless, by analyzing the annular pacchas of Cusco within a broad diachronic framework, it can be shown that annular pacchas changed over the centuries. These transformations do not follow a predictable unilineal path of increasing acculturation. In fact, the emulation of European features on annular pacchas is strongest during the Colonial Period. During this time, the annular paccha was sometimes transformed stylistically by adding curvilinear strap handles and a decorative applique band to the mouth of the vessel spout. These features are conspicuous evidence of European influence as was the occasional use of ceramic glaze and inlays of blue and green-colored glass. Ceramic glaze is an impervious vitreous layer which fuses to the ceramic body of the vessel. This technique, quite common in the Old World, was largely unknown in the Andes prior to the arrival 
of the Spaniards because vitrification required high temperatures that were beyond the technical capacity of Andean potters. Likewise, the colored glass used in the decorative inlays implies a knowledge of glass making, a technology totally foreign to prehispanic Andean cultures. The modeling of the face of an angel or cherub on the spouts of many colonial pacchas is another striking expression of European cultural influence. In this case, the angelic visage suggests something more than stylistic emulation since it involves the incorporation of a Christian religious motif into a class of traditional Andean ritual objects.

The annular pacchas discussed here were produced by Andean potters and consumed by people of indigenous descent in Cusco, and this must be taken into account in trying to understand the objects illustrated in this article. With this in mind, the incorporation of European stylistic features, technologies and religious iconography into the Colonial Period annular pacchas can be explained in different ways. It can be interpreted as a conscious or unconscious effort to appropriate elements associated with an alien high-status group that had imposed itself at the top of the socioeconomic and political hierarchy. From this perspective, the appearance of Hispanic stylistic elements on the annular pacchas may express the efforts of the local Andean population to reduce their sense of marginalization in the new socioeconomic situation through emulation. They also may have been fascinated and attracted by these unprecedented features and wanted to be linked to them.

The prominent representation of cherubs likewise can be seen as an adaptation to the changing colonial realities by embracing elements of the new religion imposed by Roman Catholic priests. Reproduction of Christian symbols such as cherubs could have been sincere, and the presence of Christian elements may have been considered as compatible with traditional Andean beliefs and rituals, much in the way that modern Peruvian curanderos utilize Catholic symbols and ritual objects together with Andean ones in their curing ceremonies. Moreover, the idea of the cherub, an anthropomorphic supernatural being with avian qualities associated with the celestial sphere is not as foreign to Andean thought as many other aspects of Catholicism. The fusing of different religious traditions was once commonly referred to as syncretism, a term signifying the blending of two or more religious belief systems into a new system, or the incorporating into a religious tradition of beliefs from unrelated traditions. In recent years, this term has fallen out of favor and been replaced by words such as hybridity. Whatever terminology is employed, the motivation behind showing images of baroque angels on Andean pacchas remains uncertain.

An alternative interpretation would be to view these European stylistic and iconographic elements as part of an effort to disguise, or at least make less conspicuous, a class of Andean religious vessels that were produced for what would have been considered pagan rituals and would therefore have been the target of campaigns to root out idolatrous behavior. From this perspective, the colonial annular pacchas would be part of the larger process of resistance and the struggle for cultural survival rather than expressions of accommodation and acculturation. It is also possible that aspects of both explanations were involved and that there may have been different understandings depending on the viewer and context.

One of the advantages of a diachronic perspective is that intractable questions of this kind can be considered within the longue durée and although no easy solution is forthcoming, new insights emerge that are relevant. For example, virtually all of the European elements adopted by annular pacchas during the Colonial Period, including those with Christian religious associations, were eliminated during the $19^{\text {th }}$ century and remain absent from the annular pacchas of the $20^{\text {th }}$ century. In contrast, during this same time, the distinctive ring-shaped chamber of the pacchas, with its symbolic associations linked to Andean cosmovision, and the representation of the Andean amaru, the mythical creature associated with precipitation for crops and herds, continue to be present. This overarching diachronic pattern suggests that the incorporation in colonial times of European elements remained of secondary or minor importance when compared to the central Andean features of the annular paccha.

While the continuity of annular pacchas from Cusco has been the focus of this article, the details of the transformations that occurred in the form and production of these vessels should not be overlooked. For example, during colonial times the spout of the annular paccha initially is situated on the front of the vessel, but it was shifted to the back of the vessel during late colonial times and remains in that location during the $19^{\text {th }}$ and $20^{\text {th }}$ centuries. Likewise, during the Colonial Period glass inlays and colored glaze painting adorn 
the pacchas, but these disappear by the $19^{\text {th }}$ century. In the $20^{\text {th }}$ century the use of pigmented slip painting is common as overall red slip and is even sometimes used for fine line decoration. But how important are these in terms of understanding the changes in post-conquest society? Some of these, like changes in the position of spouts, may simply reflect the normal process of stylistic change common to all human cultures. Like the fluctuations in the length of women's dresses or the width of men's ties in the $20^{\text {th }}$ century, these shifts in style may signify little more than the ebb and flow of time and cultural taste.

On the other hand, some long-term trends may be expressions of the changing world for those using annular pacchas in their rituals. When the colonial annular pacchas of Cusco are compared with those of the $19^{\text {th }}$ century it is hard to escape the conclusion that the $19^{\text {th }}$ century pacchas are simpler and cruder than those of the preceding centuries. While the sample is admittedly small, I do not think that this pattern is the result of sampling bias. The colonial pacchas are consistently produced at a higher level that is suggestive of involvement of specialized potters. The elaborate techniques that they utilized required considerable technical knowledge and experience. The elaborate iconography that decorates the colonial pieces likewise contrasts with the simplified and, at times, nearly unrecognizable versions of older motifs adorning the $19^{\text {th }}$ century pacchas. I hypothesize that the contrasts between the Colonial Period and $19^{\text {th }}$ century pacchas may in part reflect the status of the groups consuming these ritual vessels. Perhaps the Colonial Period pacchas were produced for the elite, or at least prosperous, occupants of the old imperial capital, while by the $19^{\text {th }}$ century pacchas were made for marginal indigenous communities in the high-altitude farmlands and grasslands. These latter groups may have lacked the sophistication and, more importantly, the economic means to demand better quality craft products. The examples of $19^{\text {th }}$ century annular pacchas discussed here seem to be the product of part-time potters with rudimentary skills, but sufficient knowledge to create simplified versions of this essential ritual libation vessel. At the same time, the lack of European features in $19^{\text {th }}$ century annular pacchas may express a conscious rejection of the urban mestizo culture of Cusco by these residents of rural indigenous communities.

The annular pacchas dating to the $20^{\text {th }}$ century show a notable improvement in the quality of production compared to those of the $19^{\text {th }}$ century, although they are still not at the level of the Colonial Period examples. Perhaps the increasing prosperity of rural Cusco and the greater integration of its communities with their urban counterparts may partially explain this shift in trajectory. Interestingly, the $20^{\text {th }}$ century annular pacchas are characterized by the representation of llamas or alpacas together with the amaru, an innovation that seems to express the integral role of these vessels in the herding rituals of high-altitude agriculturalists. While the $20^{\text {th }}$ century annular pacchas introduce numerous innovations, it is significant that none of them involve the emulation of urban or national cultural styles, and none incorporate elements drawn from Roman Catholicism.

During the $20^{\text {th }}$ century, one of the most striking alterations in the form of annular pacchas was the change from a single spout, which had characterized the vessels since the Colonial Period, to three spouts. This new pattern is reminiscent of modern ceramic cochas from Cusco which often are made with three horizontal spouts (Matos 1999: 162). A series of distinguished Andean scholars including Tom Zuidema (1964), Heather Lechtman (2007) and María Rostworowski (1983) have observed that tripartite structures are of crucial significance in Andean cosmology and social organization and that, along with dualism, these tripartite elements have acted to structure Andean culture since prehispanic times. The tripartite organization of the lines in the Inca ceque system of Cusco (collanapayan-cayao) is perhaps the best-known example of tripartite organization in the Andes. Whether this principle of Andean structuralism is relevant to the introduction of the three-spout pattern to $20^{\text {th }}$ century Cuzqueño annular pacchas remains to be determined. On the other hand, the lasting importance of dualism is amply attested to in the iconography of annular pacchas from the Colonial Period with the depiction of two serpents, paired dissimilar marine symbols, and the use of contrasting colors of glaze. In the subsequent $19^{\text {th }}$ and $20^{\text {th }}$ centuries, the representation of dual amarus attests to the continued centrality of dynamic dualism in the Andean rituals of Cusco. 


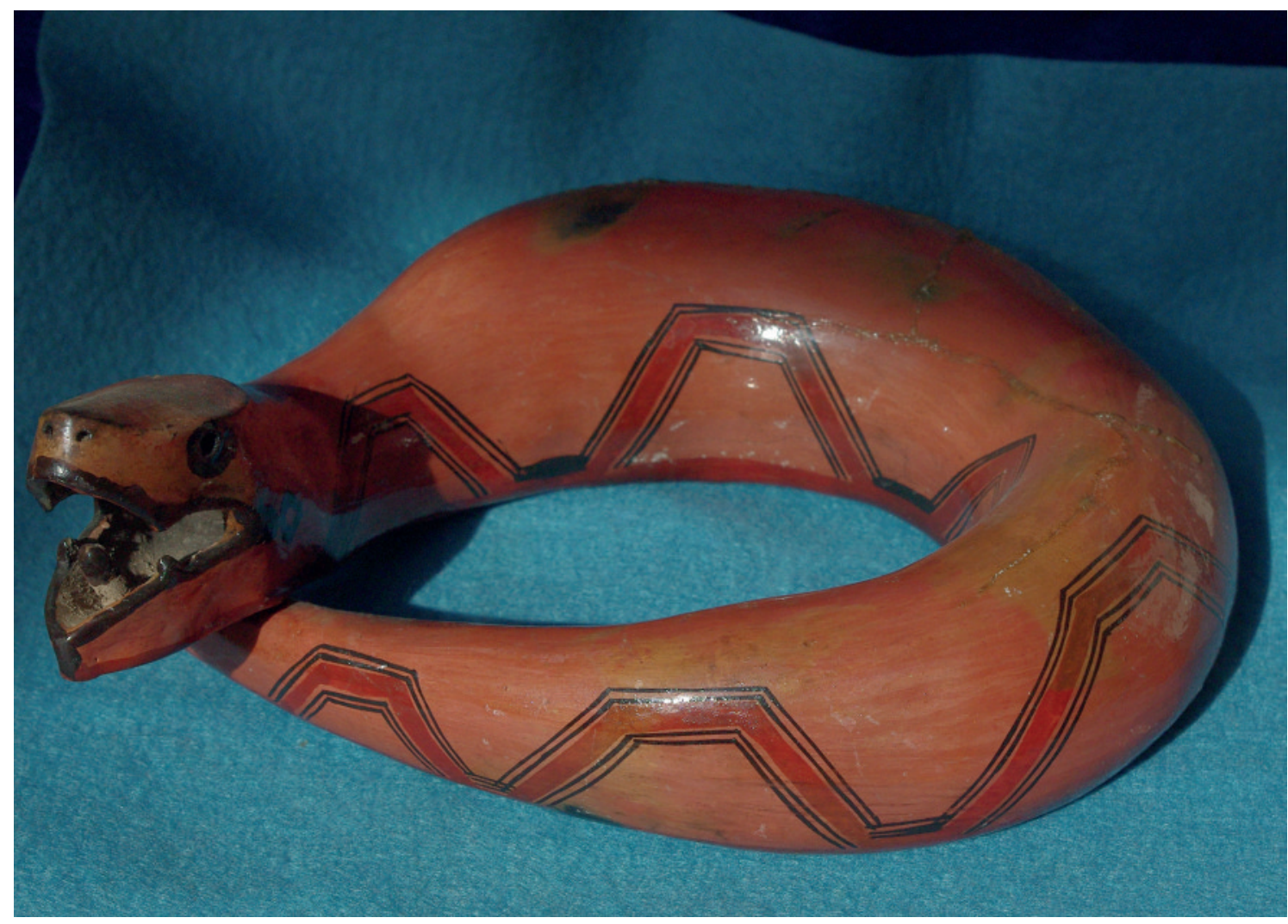

Figure 30. Contemporary ritual vessel in the form of an anaconda made by a potter of the Sacha Runa ethnic group in the eastern lowlands of Ecuador. Late $20^{\text {th }}$ century. (Photo: Norman Whitten, Jr.). Figura 30. Vasija ritual contemporánea en forma de anaconda hecha por un ceramista del grupo étnico Sacha Runa en las tierras bajas orientales de Ecuador. Siglo xx tardío. (Fotografía: Norman Whitten, Jr.).

\section{EPILOGUE}

The annular pacchas analyzed in this article were produced in Cusco during the four centuries following the Spanish Conquest, but annular pacchas also continued to be produced and used in rituals in other zones that shared in the historical legacy of the Incas. For example, I am aware of two examples of post-Conquest annular pacchas from Bolivia. Significantly, neither of these resemble the Cusco annular pacchas described here. One of the Bolivian annular pacchas, collected by Adolph Bandelier from La Paz, is now in the collection of the National Museum of the American Indian in Washington DC. According to the accession records, the vessel was made between 1880-1910. It features three modeled animal heads, perhaps of bulls, on top of the ring-shaped chamber. Another annular paccha was on display in 2017 at the archaeology museum located on the site of Tiahuanaco. The vessel is covered with brown glaze and represents a complex modeled scene in which a crowned male is shown carrying out a human sacrifice. An unusual feature of this annular paccha is that the ring-shaped chamber of the vessel is supported by modeled camelid legs. These two Bolivian pieces suggest the considerable diversity that may be revealed in future studies of annular pacchas from regions outside of the Cusco heartland.

Annular pacchas with modeled representations of serpents also are produced in the forested eastern lowlands of Ecuador among the Sacha Runa (fig. 30). These vessels resemble the Chimu-Inca annular pacchas from Peru's north coast (fig. 1). It is hard to explain how these ceramic objects could be unrelated to the ChimuInca antecedents and it seems likely that the Sacha Runa vessels are part of the long tradition that includes the annular pacchas from Cusco presented in this article. According to Norman Whitten, Jr. these ritual pottery vessels are called amarun by these Quechua-speaking 
lowland peoples (Whitten 1976: 174, Whitten \& Whitten 2016: 22). Remarkably, Whitten's ethnographic research revealed that the amarun represents the anaconda, an animal that is believed by the Sacha Runa to be the spirit master of the entire hydrosphere.

One possible explanation for the similarity between the pacchas of the Sacha Runa on the eastern Andean slopes of Ecuador and the much older Chimu-Inca pacchas of Peru's north coast would be the historic impact of camayoq, the craft specialists sent by the Inca state to distant regions of Tawantinsuyu in order to promote activities such as ceramics and metallurgy (e.g., Espinoza 1993). This same process may help to explain why the most convincing antecedents for the colonial and other post-Conquest annular pacchas of Cusco discussed here come from the Chimu-Inca potters of the Peruvian coast. Were these post-Conquest annular pacchas inspired by ceramicists brought to the Inca capital as camayoq during Inca times?

ACKNowlEdgements Rosana Abril, Catherine Allen, Estela Miranda Castillo, Tom Cummins, Ellery Frahm, Ivan Ghezzi, José Ignacio Lambarri, Jaime Liébana, Bruce Mannheim, Edith Mercado, José Luis Martínez, Christopher Phillip, Joanne Pillsbury, Jeffrey Quilter, Lucy Salazar, María Solari, Maya Stanfield-Mazzi, Patrick Ryan Williams, Norman Whitten, Jr., and two anonymous reviewers.

\section{REFERENCES}

Allen, C. J. 2002. The incas have gone inside: pattern and persistence in andean iconography. RES Anthropology and Aesthetics 42: 180-203.

Alva, W. 1986. Cerámica temprana en el valle de Jequetepeque, norte del Perú. In Materialen zur allgemeinen und vergleichenden Archäologie, vol. 32, KAVA. Munich: C.H. Beck.

Barrionuevo, A. 1963. Las ventanas de los hermanos Ayar. Caretas 275: 36-37.

BLOWER, D. 2000. The many facets of mullu: more than just a spondylus shell. Andean Past 6: 209-228.

BURGER, R. 1992. Chavin and the origin of andean civilization. London: Thames and Hudson.

CARrión, R. 1955. El culto al agua en el antiguo Perú: la paccha, elemento cultural pan-andino. Revista del Museo Nacional y Arqueología II (2): 50-140.

Cohen Suarez, A. 2016. Heaven, hell and everything in between: murals in the colonial andes. Austin: University of Texas Press.

Cummins, T. 2002. Toasting with the inkas: andean abstraction and colonial images on quero vessels. Ann Arbor: University of Michigan Press.
Cummins, T. \& Mannheim, B. 2011. The river around us, the stream within us: the traces of the sun and inka kinetics. RES Anthropology and Aesthetics 59-60: 5-21.

Duviols, P. 2003. Procesos y visitas de idolatrías. Cajatambo, siglo XVII. Lima: Fondo Editorial de la Pontificia Universidad Católica del Perú-Instituto Francés de Estudios Andinos.

EspinOZA, W. 1993. Los mitmas ajiceros-maniceros y los plateros de Ica en Cochabamba. Historia y Cultura 22: 47-74.

Flores OchoA, J., KuOn, E. \& SAmAnez, R. 1998. Qeros: arte inka en vasos ceremoniales. Lima: Banco de Crédito del Perú.

GäNGER, S. 2014. Relics of the past: the collecting and studying of Pre-Columbian antiquities in Peru and Chile, 1837-1911. Oxford: Oxford University Press.

GuevarA, A. 1997. La contribución de José Lucas Caparó Muñiz a la formación del Museo Arqueológico de la Universidad del Cuzco. Boletín del Instituto Riva-Agüero 24: 167-226.

Jones, J. 1985. The art of precolumbian gold. The Jan Mitchell collection. Boston: Little, Brown and Company.

Joyce, T. 1922. The "paccha" of ancient Peru. The Journal of the Royal Anthropological Institute of Great Britain and Ireland 52: 142-149.

Kubler, G. 1961. On the colonial extinction of the motifs of pre-columbian art. In Essays in pre-columbian art and archaeology, S. Lothrop, ed., pp.14-34. Cambridge: Harvard University Press.

Lathrap, D., Collier, D. \& Chandra, H. 1975. Ancient Ecuador: culture, clay and creativity 3000-300 BC. Chicago: Field Museum of Natural History.

Lechtman, H. 2007. The inca and andean metallurgical traditions. In Variations in the expression of inca power, R. Burger, C. Morris \& R. Matos, eds., pp. 313-355. Washington DC: Dumbarton Oaks.

Lothrop, S. K. 1950. Peruvian pacchas and keros. American Antiquity 21 (3): 233-243.

Martínez, F. 2009. Del amaru al toro. Lima: Instituto Nacional de Cultura.

Matos, R. 1999. La cerámica inca. In Los incas, F. Pease, ed., pp. 108-167. Lima: Banco de Crédito del Perú.

Mujica, R., Sarria, L., Hare, B. \& Bryce, A. 2011. Del cielo y la tierra: la colección de arte popular peruano de Vivian y Jaime Liébana. Lima: Fondo Editorial de la Universidad San Martín de Porres.

Ortmann, D. 2002. Ciencias de la religión en el Perú. Lima: Universidad Nacional Mayor de San Marcos.

Phipps, E., Hecht, J. \& Esteras, C. 2004. The colonial andes: tapestries and silverwork, 1530-1830. New York: Metropolitan Museum of Art.

Pillsbury, J. 2003. Luxury arts and the lords of Chimor. In Latin American Collections: essays in honor of Ted J. Leyenaar, D. Kop Jansen \& E. Bock, eds., pp. 67-81. Leiden: Tetl.

QUiLter, J. 1997. Continuity and disjunction in pre-columbian art and culture. RES Anthropology and Aesthetics 29-30: 303-318. 
Rostworowski, M. 1983. Estructuras andinas del poder: ideología religiosa y política. Lima: Instituto de Estudios Peruanos.

RowE, J. 1961. The chronology of inca wooden cups. In Essays in pre-columbian art and archaeology, S. Lothrop, ed., pp. 317-341. Cambridge: Harvard University Press.

Stasny, F. 1991-1992. Pacchas coloniales y jarras de engaño. Historia y Cultura 21: 231-245.

Sundstrom, L. \& DeBoer, W. 2012. Enduring motives: the archaeology of tradition and religion in native America. Tuscaloosa: The University of Alabama Press.

Ulfe, M. 2004. Danzando en Ayacucho. Música y ritual del Rincón de los Muertos. Lima: Centro de Etnomusicología Andina, Instituto Riva-Agüero, Pontificia Universidad Católica del Perú.
VALDEZ, F. 2013. Las primeras sociedades de la Alta Amazonía: la cultura Mayo-Chinchipe-Marañon. Quito: Institut de Recherche pour le Développment.

Whitten JR., N. 1976. Sacha Runa: ethnicity and adaptation of ecuadorian jungle quichua. Urbana-Champaign: University of Illinois.

Whitten, D. \& Whitten JR., N. 2016. From myth to creation: art from amazonian Ecuador. Urbana-Champaign: University of Illinois.

Zuidema, T. 1964. The ceque system of Cusco: the social organization of the capital of the Inca. Leiden: E. J. Brill. 